folk/ed. Derg, 2021; 27(3)-107. say1

DOI: $10.22559 /$ folklor.1602

\title{
Ölü Gömme Gelenekleri Bağlamında Berel Kurganları*
}

\author{
Berel Kurgans within the Context of Funeral Rites
}

\author{
Mehmet Kutlu* \\ Leila Kutlu**
}

Öz

Altay Dağlarının güneybatı ucunda bulunan Berel Vadisi’nde sayıları yüzü aşan kurgan bulunmaktadır. İlk kez 1865 yılında Wilhelm Radloff tarafından kazısı gerçekleştirilen Berel'deki kurganların birinde permafrost katmanları tespit edilmiştir. Bu özelliğe sahip bir kurganın merkezindeki derin çukura ahşap tomruklardan inşa edilmiş defin odaları konumlandırılmıştır. Söz konusu ahşap defin odalarında ve tek parça tomruktan oyulmuş ahşap lahitte insan ve çok sayıda at gömüleri tespit edilmiştir. Ancak zamanın kazı yöntemleri ve arkeolojik buluntuları muhafaza imkânlarının yeterli olmaması nedeniyle söz konusu insan ve at gömüleri korunamamıştır. Daha sonra Berel

Geliş tarihi (Received):07.01.2021 - Kabul tarihi (Accepted): 29.06.2021

* Bu araştırma 2019BSP11 numaralı proje kapsamında Pamukkale Üniversitesi Bilimsel Araştırmalar Projeleri tarafindan desteklenmiştir.

,** Doç.Dr. Pamukkale Üniversitesi, Fen-Edebiyat Fakültesi,Sanat Tarihi Bölümü (Faculty of Arts and Sciences, Department of Art History)mehmetkutlu@pau.edu.tr. ORCID 0000-0002-3075-3965

*** Yüksek Lisans Öğrencisi, Pamukkale Üniversitesi, Sosyal Bilimler Enstitüsü, Sanat Tarihi Anabilim Dalı, (Graduate Student, Pamukkale University, Institute of Social Sciences, Department of Art History)

lkutlu18@posta.pau.edu.tr. ORCID 0000-0003-4367-8260 
Vadisi'ndeki kurganlar yaklaşık 150 yıla yakın süre boyunca kapsamlı bir şekilde kazılmamış ve incelenmemiştir. Bu durum 1998 yılında Prof. Dr. Zainolla Samashev'in ekibiyle birlikte Doğu Kazakistan Arkeolojik ekspedisyonu kapsamında Berel'de geniş çaplı kazılar yürütmeye başlamasıyla değişmiştir. 10. ve 11. Kurganlarda da saptanan permafrost (kalıcı don) katmanları olgusu sıradan kurganlarda korunamayan organik materyallerden yapılmış sanat eserlerinin yanı sıra insan ve at kalıntılarının günümüze ulaşmasına ve incelenebilmesine olanak sağlamıştır. Bu çalışma, Berel kurgan mezarlığında bulunan İskit/Saka, Hun, Hsiyen-pi ve Göktürk dönemlerine ait kurganları ölü gömme gelenekleri bağlamında ele alıp incelemektedir. Antropolojik araştırmalar ve ölü gömme gelenekleri üzerine yapılan değerlendirmelerin sonucunda ortaya konulan benzerlikler, İskit döneminden Göktürk dönemine kadar kültürel süreklilik veya devamlılık olgusuna dair kanıtlar sunmaktadır.

Anahtar sözcükler: Berel kurganlarl, İskit, Hun, Göktürk, ölü gömme gelenekleri, atlı gömü

\begin{abstract}
:
Permafrost layers under the stone kurgans at Berel Valley located at the southwestern slopes of Altai Mountains, was initially discovered by Wilhelm Radloff in 1865. It had been revealed that there was a deep pit with the burial chambers made of timbers at the center of a kurgan with permafrost layers. Burial chambers, where wooden sarcophagus carved from a single piece of log were placed, had also contained human remains and many horse burials. However, the human and horse burials could not be preserved due to the insufficient technological and methodological conditions in excavation and protection of the findings at that time. Berel Kurgans had not extensively excavated and studied for nearly 150 years until Prof. Zainolla Samashev leading East Kazakhstan Archeological Expedition, initiated large-scale excavations at Berel in 1998. As a result, permafrost layers were detected in the 10th and 11th kurgans. Organic artifacts along with the remains of human beings and horses that cannot be preserved in ordinary kurgans reached nowadays and provided an opportunity to examine them. The purpose of the current research is to examine the kurgans of the Scythian, Hsiung-nu, Xianbei and Turkic khaganate periods in the Berel within the context of burial rites and customs. Some similarities in burial rites determined as a result of anthropological evaluations presents evidence of cultural continuity from the Scythian to the Turkic khaganate periods.
\end{abstract}

Keywords: Berel kurgans, Scythian, Hsiung-nu, Turkic khaganate, burial rites, horse burial

\title{
Extended summary
}

Berel burial ground, which located in southwestern slopes of Altai Mountains, consists of kurgan groups of various sizes. According to the latest data there are more than 100 kurgans 
identified. Most of them are concentrated in two parts of the triangular terrace, namely the $1^{\text {st }}, 2^{\text {nd }}$ and $3^{\text {rd }}$ kurgan groups in the middle part of the terrace while the $4^{\text {th }}$ group located in the western part. Only the first and fourth groups are in the form of long chains of kurgans lined up in a linear order in the north-south and northwest-southeast directions. Other kurgans are arranged in a few small rows or irregularly. Each of the kurgan groups, which consists of several kurgans, is considered to belong to members of a family or a dynasty. The majority of Berel Kurgans date back to the IV-III centuries BC and defined as Pazyryk Culture. However, throughout the excavations of more than 100 kurgans being conducted in Berel since 1998, it was possible to obtain a number of materials dating to later periods than Pazyryk, namely Hsiung-nu, Xianbei, Early Turkic and Turkic Khaganate periods. There are 5 types of kurgans in relation to their architecture. According to their functional characteristics, material findings were classified into four categories such as ceremonial-ritual items, clothing, household items and tools and horse harnesses. Current research deals with the kurgans of the Scythian, Hsiung-nu, Xianbei and Turkic khaganate periods in the Berel burial ground within the context of burial customs. After the participation in East Kazakhstan Archaeological Expedition in the summer of 2019, examination of material findings exhibited in Berel museum, literature review and anthropologic assessment of Berel kurgans and their architecture it is possible to reveal common characteristics and consistent regularity with regards to burial rites. The common features identified in Pazyryk period kurgans of Berel are the practice of horse burial ranging in number from 1 to 17 , the burial of the people in the sarcophagi carved from a single piece of larch placed into the wooden made burial chamber, eastward orientation of human bodies lying on their backs as well as eastward orientation of horses. Elements of horse harnesses of the period were created or decorated in animal style. In addition to this, putting food made of lamb, weapons, daily use items and other household items in the burial chambers is the other common characteristic in terms of burial tradition.

The kurgans of post-Pazyryk time differ from those of Scythians in size, architecture, and material culture. Mostly those kurgans are in forms of deep graves surrounded by low stone fences covered with dense vegetation. Even though most of coffins in burial pits of Hsiung-nu period were made of stone material there are some graves with timber chambers similar in technique to those of Pazyryk period. Some of the kurgans contain horse burials and formed in two layers. Usually, horses were buried at upper pit, in other words closer to the surface. Although most of this type kurgans had been previously robbed, the archaeologists unearthed some materials like accessories equipping horse tack and some arms. Findings such as three-winged sharp iron arrowheads, bone pieces of Hsiung-nu type compound bow as well as ancient Chinese mirror dating to Han dynasty period clearly indicates Hsiung-nu and following Xianbei historical periods. Despite the apparent change in material culture, it is still possible to observe similarities in burial customs among the kurgans of Pazyryk, Hsiungnu and Xianbei periods at Berel. It originates as eastward orientation of human bodies placed on their back and eastward orientation of horses. Like during Pazyryk period people were equipped with weapons and horses accompanying them were also harnessed.

There are small number of kurgans of Turkic period. Polygonal or circular in shape Turkic 
kurgans have dome like stone superstructure over burial pit or surrounded by stone fences. Funeral rites remain unchanged when compared with earlier periods in that bodies of humans have eastward orientation. Burial of harnessed horses is another unchanged characteristic practice. Furthermore, the placement of balbals on the east of kurgans is another common feature for the kurgans of Pazyryk and Turkic period.

Dromoses of Early Scythian kurgans located in the territory of Kazakhstan such as Shilikti, Taldy 2, Eleke Sazy have eastern orientation. Doors of Hsiung-nu yurts also oriented to the east. It is well known from ancient Chinese written sources and from memorial complexes of rulers Turkic Khaganates that east has a particular significance in Early Turkic culture. As the funeral rites are strictly followed and hardly changed, they can be considered as markers of cultural continuity. Thus, it can be concluded that there is cultural continuity in terms of kurgan-based burial rites from the Scythian to the Turkic khaganate periods in case of Berel burial ground. Consequently, Berel burial ground can be related to Proto-Turkic nomadic Ting-Ling tribes. Therefore, Berel is important burial ground which provides reach materials for resolving issues related to the history of Proto-Turkic people and their early culture.

\section{Giriş}

Berel Vadisi, Kazakistan Cumhuriyeti'nde Doğu Kazakistan Vilayetinin Katonkaragay ilçesi sınırları içindeki Berel ve Jambıl köyleri arasında uzanmaktadır. Buktırma nehrinin kolları ve dik dağ yükseltileriyle çevrelenmiş Berel Vadisi’nde yer alan kurgan mezarlığı ise aynı adı taşıyan köyün yaklaşık 7 km güneybatısındadır. Buktırma nehrinin aktığı vadi tabanından yaklaşık olarak 75 m yükseklikteki üçgenimsi bir yüksek düzlük üzerinde kurganlar bulunmaktadır. Söz konusu düzlüğün deniz seviyesinden yüksekliği 1120 m olarak ölçülmüştür (Samashev vd., 2000:9).

Berel Kurgan Mezarlığı çeşitli büyüklükteki kurgan gruplarından oluşmaktadır. Son verilere göre, mezarlıkta 100'den fazla kurgan olduğu belirtilmektedir (Samashev vd., 2018:40). Kurganların büyük çoğunluğu üçgenimsi şekildeki terasın iki bölümünde, yani orta kısımda I.-II.-III. grup ve batı kısmında IV. grup olmak üzere yoğunlaşmıştır (Görsel. 1). Adı geçen dört grup, kurganların kümeleşme özelliğine göre tanımlanmıştır. Bunlardan yalnızca birinci ve dördüncü gruplar, kuzey-güney ve kuzeybatı- güneydoğu yönlerinde, adeta bir çizgisel düzende sıralanan uzun kurgan zincirleri şeklindedir. Diğer kurganlar ise birkaç küçük sıra oluşturacak şekilde veya düzensiz konumlanmaktadır. Kurgan zincirlerinin yönü definlerin doğrultusuna diklik ilkesine göre belirlenmiş ve bu uygulamaya sıkı sıkıya bağlı kalınmıştır (Samashev, 2011: 34). 


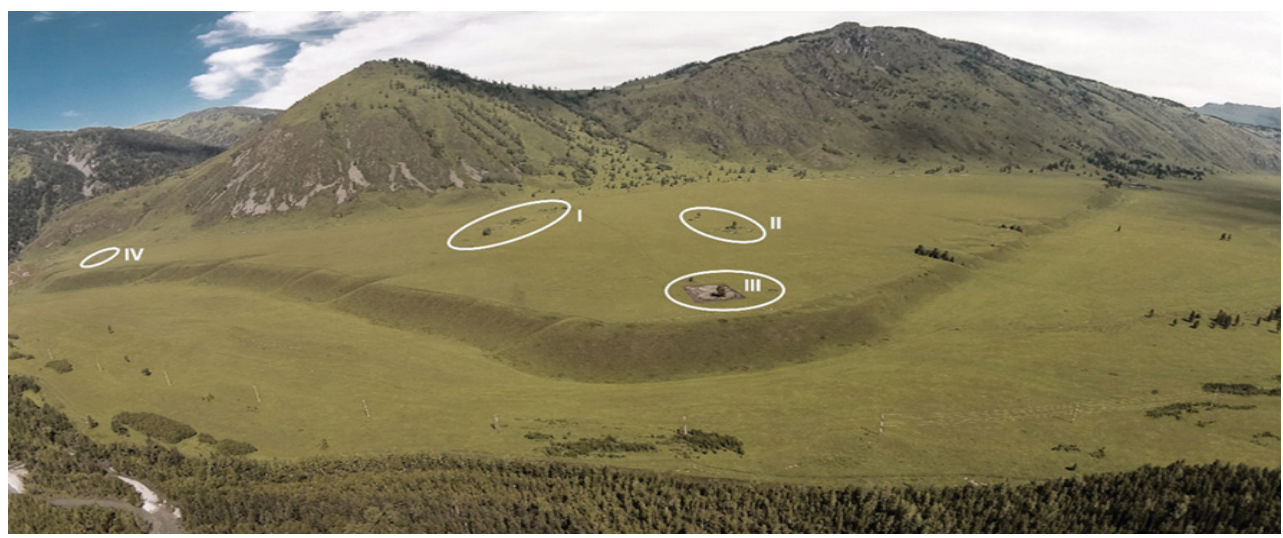

Görsel 1: Berel vadisinin güneyden görünüşü ve kurgan gruplarının kümelenmesi.

(Z. Samashev, 2011).

Birkaç kurgandan meydana gelen kurgan gruplarının her birinin aralarında akrabalık bağı bulunan aile veya hanedanın üyelerine ait oldukları düşünülmektedir. Berel Kurganlarının çoğunluğu M.Ö. IV- III. yüzyıllara tarihlendirilmektedir. I., II. ve III. gruplar büyük ve küçük boyuttaki kurganlardan oluşurken, üçgenimsi terasın batı kenarında yer alan IV. grup ise atlı gömü ve sıradan buluntu envanteri içeren küçük boyutlu kurganlardan meydana gelmektedir (Samashev, 2011:34, Kutlu \& Kutlu, 2020: 175-177).

İskit/Saka(1) dönemi kurganları:. M.Ö. IV.- III. yüzyıllara ait kurganları tanımlamaktadır. Bu kurganlar arasında I. gruptan elips veya oval planlı taş örtüye sahip 4., 8., 9., 10., 11. ve 36. kurganlar, II. gruptan üst örtüleri dairesel biçimli ve kendi arasında taş yollarla birbirine bağlanmış 16., 18. ve 19. kurganlar, III. gruptan ise 2. kurgan ile Wilhelm Radloff'un kazısını gerçekleştirdiği 1. Büyük Berel Kurganı ile IV. gruptan düz bir çizgisel doğrultuda zincir şeklinde sıralanan 30., 31., 32., 33., 34., 40. ve 41. kurganlar bulunmaktadır (Samashev, 2011: 47-103).

Hun ve Hsiyen-pi dönemi kurganları: Berel'de Hun-Hsiyen Pi dönemi kurganları genel olarak M.Ö. III.-M.S. V. yüzyıllar arasına tarihlenmektedir. (Samashev vd., 2018:16) $\mathrm{Bu}$ grupta yer alan kurganlarda Hun dönemi: M.Ö. III.-M.S. II yy. arasına; Hsiyen -pi dönemi ise M.S. II.-V. y. arasına karşılık gelmektedir (Samashev vd., 2016:251). Söz konusu kurganlar genellikle Berel'in Pazırık dönemine ait kurganlarının doğu ve güney taraflarına bitişik (Görsel 2), ancak bazıları onlardan biraz uzakta konumlandırılmıştır (Samashev vd., 2019: 385-393).

Berel'deki Hun-Hsiyen Pi dönemi kurganlarının ilk kez 1865 yılında W. Radloff tarafından incelenmiştir. Radloff, III. gruptaki İskit dönemine ait 1. ve 2. kurganların etrafında hem mimari hem de buluntu bağlamında farklılık gösteren taş çitlerle çevrili küçük ve orta boyutlu Hun-Hsiyen Pi kurganlarının bazılarının kazısını yapmıştır.

Bu döneme ait kurganlara dair çalışmalar son yıllarda yoğunluk kazanmakta ve Prof.Dr. 
Zainolla Samashev başkanlığında yürütülmektedir. Örneğin, 2015- 2018 yılları arasında HunHsiyen Pi dönemi olarak tanımlanan 67C, 68, 90, 105, 108 ve 108A olarak numaralandıran kurganların kazıları gerçekleştirilmiş ve arkeolojik buluntuları incelenmiştir (Samashev vd., 2018:16). 2019 yılında ise Berel mezarlığında 15'i taş tabuta, 15'i ise çukura defnedilen toplam 30 gömünün saptandığ1 58 kurgan ve mezar çitinin kazısı yürütülmüştür. Söz konusu kurganların bazılarının boş olduğu veya gelecekte olası gömüler için hazırlanmış olduğu şeklinde yorumlanmaktadır (Samashev vd., 2019: 387).

Berel'de Hun-Hsiyen Pi dönemi kurganlarındaki buluntular içinde "Hun tipi" olarak tanımlanan bileşik yaylara ait kemik yay güçlendirme parçalarının bulunması da dikkat çekmektedir. Orta Asya silahları uzmanı olarak kabul edilen Yuli Hudyakov'un tanımlamaları ve kurgan buluntularına göre "Hun tipi yaylar" yaklaşık olarak 1,50 m uzunluğundaki güçlendirilmiş bileşik yaylardır. Yayın gövdesini oluşturan ahşap iskelete tutkalla çeşitli malzemelerden yapılan parçalar yapıştırılır ve yay iskeletinin orta (kabza) ve uç kısımları (başları) kemik veya boynuzdan yapılan parçalarla güçlendirilir. Yayın başlarına bazen tutkalla bazen de geçmeli olarak tasarlanan demir veya boynuzdan imal edilmiş parçalar tutturulur. Hun yaylarının başlarının güçlendirme parçaları uzun, hafif eğimli ve kanatlara doğru daralmaktadır. Gerekli uzunluklara sahip kemik veya boynuz parçalarının olmadığı durumlarda birkaç küçük parçanın birbirine yapıştırılmasıyla ihtiyaç duyulan uzunlukta parça elde edildiği görülür. Yayın orta kanat parçaları geniş ve eğik kesim kenarlı olup güçlendirme amaçlı tasarlanmıştır. Bununla birlikte "Hun tipi” yaylarının ahşap gövdesinin kabza kısmına ön (frontal) güçlendirme parçaları eklenmektedir. Bu parçalar uzun, ince olup kenarlarına doğru genişlemektedir. Kemik parçalar ahşap gövdenin gerilme ve sıkıştırma kuvvetlerine maruz kalan bölgelerine uygulanır. Bu parçalar gerilme ve sıkıştırma bölgelerinde oluşabilen istemsiz bir bükülmeyi engellemek amacıyla eklenmiştir. Ön parça dışındaki diğer parçalar kırılma yaratabilen sıkıştırma kuvvetine maruz kalan yayın bükülmesini önlemektedir. Hun yaylarının kabza ve iki başında toplam 3 sertlik bölgesi ve kanatlarında esnek ve bükülebilen 2 esneklik bölgesi bulunmaktadır. Bu yaylar, 1,50 m kadar geniş kanat açıklıkları ve uzun gövdeleri sayesinde okları uzak menzillere kolayca ulaştırabilmektedir. Ayrıca bu tip yaylarla at sırtında atış yapmayı kolaylaştırmak için yayın alt başı üst başından daha kısa yapılabilmektedir (Hudyakov, 1986: 26-30, Nikonorov\& Hudyakov, 2004: 45-51).

Berel'deki bazı kurganlarda üç kanatlı, keskin demir ok uçlarıyla birlikte konulan Hun tipi yay güçlendirme parçalarının tespit edilmiş olması söz konusu kurganları (40A, 82A, 82B) Hun dönemine tarihlendirmeye olanak sağlamaktadır. 2019 yılında kazıları yapılan Hun dönemine tarihlenen bu üç kurganda definlerin Pazırık kültürü kurganlarında olduğu gibi ahşap defin odalarına yapıldığı gözlemlenmiştir. Bununla birlikte kazılarda Hermitage Müzesi koleksiyonlarında benzerleri bulunan ve M.Ö. III. yüzyıla tarihlenen Han hanedanı dönemi Çin yapımı ayna saptanmıştır. Bu tür buluntular da tarihlendirmeye dayanak teşkil etmektedir (Samashev vd., 2019:387-391).

Göktürk dönemi kurganları: Berel'de Göktürk dönemi kurganları M.S. V-VIII 
yy. arasına tarihlenmektedir. (Samashev, 2011:47, Samashev vd., 2016:251). Bu dönem kurganları kronolojik olarak iki kategoride ele alınmaktadır. Buna göre ilk örnekler Erken Türk dönemi olarak tanımlanırken M.S. V.-VI. yüzyıllara tarihlenmekte, dönemin ana karakteristiğini yansitan kurganlar ise Göktürk dönemi olarak tanımlanmakta ve M.S. VI VIII. yüzyıllara tarihlendirmektedir (Samashev vd., 2016:251).

1998-2011 yılları arasında Göktürk dönemine tarihlenen 16 C kurganıyla 25., 37. ve 38. kurganların kazıları gerçekleştirilmiş ve arkeolojik buluntuları değerlendirilmiştir (Samashev vd., 2018:16).

Hun-Hsiyen Pi ve Göktürk dönemi kurganları genellikle geniş çaplı, oval veya dairesel biçimli taş örtüye sahip ve çizgisel doğrultuda konumlanan İskit/Saka dönemi kurganlarından hem mimari hem de buluntu bağlamında farklılık göstermektedir. Boyut olarak daha küçük olmalarıyla birlikte buluntu yönünden daha mütevazi kurganlardır. Ayrıca Göktürk kurganları, Hun-Hsiyen Pi kurganlarından da mimari özellikleri yönüyle ayırt edilebilmektedir. Göktürk kurganları bazen doğru olmayan dikdörtgen veya bazen oval biçimli oldukça sağlam taş çitlerle çevrili orta ve küçük boyutlu kurganlardır. Örneğin 25. kurganın çapı yaklaşık olarak $12 \mathrm{~m}$ ve örtü planı oval iken 38. kurganın planı kareye yakın dikdörtgen olup boyutları yaklaşık 4,60 x 4,30 metredir (Samashev, 2011:104-108).

Bu kurganlardaki definler çeşitlilik göstermekte olup tek kişilik (68., 90., 25. ve 37. kurgan), iki kişilik (68. kurgan), sadece at gömüleri (67C kurganı) ve bazen insan ve atlar iki farklı seviyede olup atlar genelde insanlardan daha yüksekte (108C ve 108A kurganları), yani yüzeye daha yakın konumlandırılmaktadır. Definler genelde Sakalarda olduğu gibi ahşap defin odalarında değil kayrak taşlardan yapılan taş tabutlara (68., 90., 105.,108. kurganlar) veya doğrudan toprağa yapılmıştır (Görsel 5, 6).

Göktürk dönemine tarihlenen 37. Kurganın güneydoğu kısmında 2 adet yüksek olmayan balbal tespit edilmiştir. Aynı kurganın mezar çukurunun batısında $1.30 \mathrm{~m}$. yüksekliğinde bir dikilitaş daha tespit edilmiştir. $1 \mathrm{~m}$ derinliğindeki mezarda başı doğuya dönük ve sırt üstü yatırılmış bir erkek cesedi saptanmıştır. 25. kurganda bulunan madeni mızrak uçları, ıslıklı ok (çavuş oku) uçları, madeni köstek tokası, kemer tokaları, madeni at gemleri tipolojik olarak bu kurganın Göktürk dönemine aidiyetini açıkça göstermektedir (Samashev, 2011:106).

Hun ve Göktürk dönemine ait kurganların-mezarlıktaki en büyük Saka kurganlarının etrafında yoğun olarak konumlanması Prof. Zainolla Samashev'e göre bu toplulukların atalarının mezarlarına yakın olma isteklerini vurgulamakta olup eski kurganlarda yatanlarla aralarında belirli bir akrabalık bağının varlığının ilanına işaret etmektedir (Samashev, 2011: 98). Benzer durum Pazırık kültürüne ait diğer kurgan mezarlıklarında görüldüğü gibi Eleke Sazı ve Esik kurgan mezarlığında da gözlemlenebilmektedir (Kutlu, 2020c:264, Kutlu, 2020d:16). 


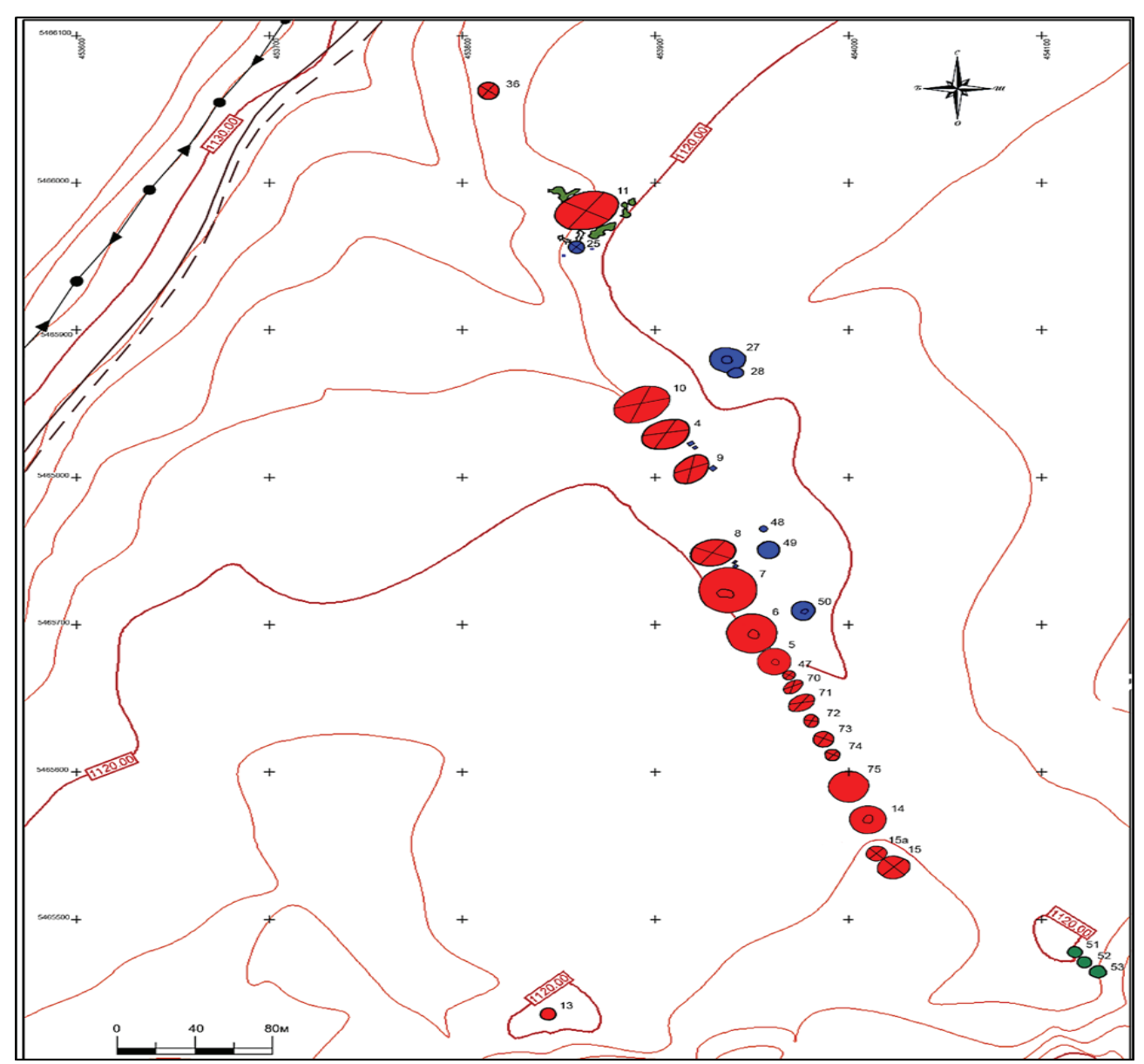

Görsel 2: Berel mezarlığındaki 1. grup kurganlar = kırmızı: İskit dönemi, yeşil: Hun-Hsiyen Pi, mavi: Göktürk dönemi (Samashev, 2011)

\section{Kurganların tarihlendirilmesi}

Berel Kurganlarında ilk kazı çalışmalarını yürüten ve yayınladığı Aus Sibirien adlı kitabında verdiği bilgilerle bilim camiasına tanıtan Wilhelm Radloff'tur. Radloff 1 . Berel ve Katanda kurganlarını tahmini olarak Erken Demir Çağı'na tarihlemekle birlikte kazılarını gerçekleştirdiği bu kurganların Türk halklarına ait olduğunu özellikle belirtmektedir (Radlov,1989: 477).

Sovyet döneminde 1929 yılında gerçekleştirilen 1. Pazırık kurganı kazısı sonrasında M. Gryaznov ise Pazırık, Katanda, Berel ve Şibe kurganlarını "Saka/İskit Çağına" tarihlendirmiştir (Gryaznov,1930:978-979).

S. Kisilev ise 1934 yılında kazısını gerçekleştirdiği 2. Karakol Kurganı’nı 1. Berel Kurganı ve Şibe’yle kıyaslayarak M.Ö. II. yüzyıla tarihlendirmektedir (Kisilev,1935:97-106). 
1930’lu yılların sonunda ise M. Gryaznov, Altay’ın Erken Göçebe Kültürlerinin gelişim aşamalarını Pazırık ve Şibe dönemlerine ayırmakta ve Şibe, Berel, Katanda, Kuray, Karakol, Tuyakta, Kurota kurganlarını M.Ö. II. ve I. yüzyıla yani Hun dönemine tarihlendirmektedir (Gryaznov, 1939: 407).

1949-1951 yıllarında S. Kisilev, 1. Pazırık, Şibe, Berel, Katanda ve diğer Altay kurganlarının "Hun-Sarmat dönemine" ait olduğunu savunmaya devam etmiştir (Kisilev,1951:105).

1969'da S. Sorokin, 1. Berel Kurganı'nın dönemi hakkında kesin bir tarih vermekten kaçınılması gerektiğini vurgular ve arkeolojik paralelliklerden dolayı Altay'ın Pazırık kurganlarıyla çağdaş olduğunu belirtir (Sorokin,1969:225). Çernikov ise 1975'te 1. Berel Kurganı'nı Hun-Sarmat döneminden ziyade Saka-İskit dönemine daha yakın değerlendirerek M.Ö. V.-III. yüzyıla tarihlemiştir (Çernikov, 1975:133). Kadırbayev ise Doğu Kazakistan'ın Demir Çağı kültürlerini inceleyip Berel dönemini tanımlar ve 1. Berel kurganını M.Ö. V.-IV. yy. tarihler (Kadırbayev, 1977). L. Marsodolov ise Büyük Berel Kurganını M.Ö. V. yüzyıla tarihlemiştir (Marsadolov, 1988:24-26).

Bununla birlikte M. Gryaznov, 1980’lerde de 1. Berel ve Şibe kurganlarını M.Ö. II-M.S. I. yüzyıllara tarihlendirmekte ve Hun-Sarmat dönemine ait olduklarını savunmaya devam etmektedir. Lakin 1992 yılında yayınlanan "SSCB Arkeolojisi” adlı kitapta, Gryaznov'un vefatı nedeniyle yayın editörleri tarafından düzenlenen metinde 1. Berel Kurganı daha erken döneme, yani M.Ö. V-III yüzyıllara tarihlenmiştir (Gryaznov, 1992, 164).

Z. Samashev ise son yıllarda yürütülen kazılar sonucunda radyo-karbon yöntemine göre 11. Berel Kurganının mutlak tarihinin M.Ö. 322 yılı olarak belirlendiğini, lakin \%95'lik bir olasılıkla M.Ö. 355-280 yılları aralığına tarihlenebileceğini ifade etmiştir. Ayrıca dendrokronolojik analizler neticesinde 11. Kurganın (M.Ö. 297), 1. Kurgandan (M.Ö. 363) yaklaşık 66 yıl sonra inşa edildiği sonucuna ulaşılmış ve her iki yöntemle elde edilen tarihler uyumlu olmuştur (Samashev 2011b:235). Genel olarak yapılan çalışmalar, Berel'in İskit dönemi kurganlarını Pazırık kültürünün bir kolu olarak değerlendirmekte ve M.Ö. IV. yüzyılın sonu ile M.Ö. III. yüzyılın başı arasındaki bir zaman dilimine tarihlendirmektedir.

\section{Kurganların yapısal özellikleri ve permafrost olgusu}

Berel kurganları, mimari özellikleri ve boyutlarına göre büyük, orta ve küçük olarak sınıflandırılmaktadır. Ayrıca kurganlardaki değerli maden ve taşlarla süslenmiş ihtişamlı objelerin sayısı ve niteliğine göre de sınıflandırma yapılmaktadır. Örneğin, iktidar sembolü olduğu kabul edilen asa, kamçı, maskeli "boynuzlu" atlar ve diğer statü göstergesi nesneler, o dönemin atlı göçebe toplumundaki hanedan üyeleri, üst düzey yöneticiler, komutanlar, din adamları ve önemli savaş kahramanları ile ilişkilendirilmektedir (Görsel 3). Kurganların büyüklüğü, inşa özellikleri ve karmaşıklığı ile mezar odasında bulunan eşyaların ihtişamı ve defnedilen atların sayısı kurgan sahibinin ait olduğu toplumsal tabakanın bir göstergesi olarak düşünülmektedir (Ongaruly, 2008: 110-117). 
Kurganların böylesine birçok yönden sınıflandırılabilecek özelliklere sahip olması Pazırık kültürüne ait atlı göçebe boylarında toplumsal tabakalaşmanın ve karmaşık bir toplumsal örgütlenmenin varlığına bir işarettir. Ancak bu özellik sadece Pazırık Kültürüne özgü değil çağdaşı olan Avrasya'nın diğer Proto-Türk göçebe bozkır kültürlerinde de görülmektedir. Örneğin, benzer unsurlar Karadeniz'in kuzeyinde yayılma gösteren İskitlerin mezar uygulamalarında da tespit edilmiştir (Samashev, 2011: 42).

Berel kurganlarının taş malzeme ile inşa edilen örtü katmanlarının altında doğal ortamdaki şartlardan oldukça farklı 1sı koşullara sahip tabakalara rastlanmıştır. Burada donma şiddetine göre farklılık gösterebilen oldukça derin mevsimsel donma, geçici donma ve aynı zamanda kurgan altı donması olarak da adlandırılan orta şiddetli permafrost koşulları oluştuğu tespit edilmiştir. Daha önceleri açıklanamayan kurganlardaki permafrost özelliğin oluşumu Berel Kurganlarında yapılan araştırmalar sonucunda açıklanabilmiştir. Buna göre kurganların taş “yı̆̆ınları” bol gözeneklidir ve üzerinde kalıcı bir kar örtüsü oluşmamaktadır. Bununla birlikte, taş malzemeler (alt Paleozoik metamorfik kayaçlar ve silttaşlar) yüksek bir 1sı iletkenliğe sahiptir. Bu koşullar soğuk dalgalarının kurganların tabanlarına kadar çok derinlemesine nüfuz etmesine neden olur. Bu etki doğal koşullarda da izlenebilir. Böylece, kaba yonu çakıl ve kolüviyal katmanlarla örtülü bölgeler, çevredeki bitki örtüsüyle kaplı sıradan kısımlara göre daha derinlemesine donmaktadır (Gorbunov vd, 2005: 30-31).

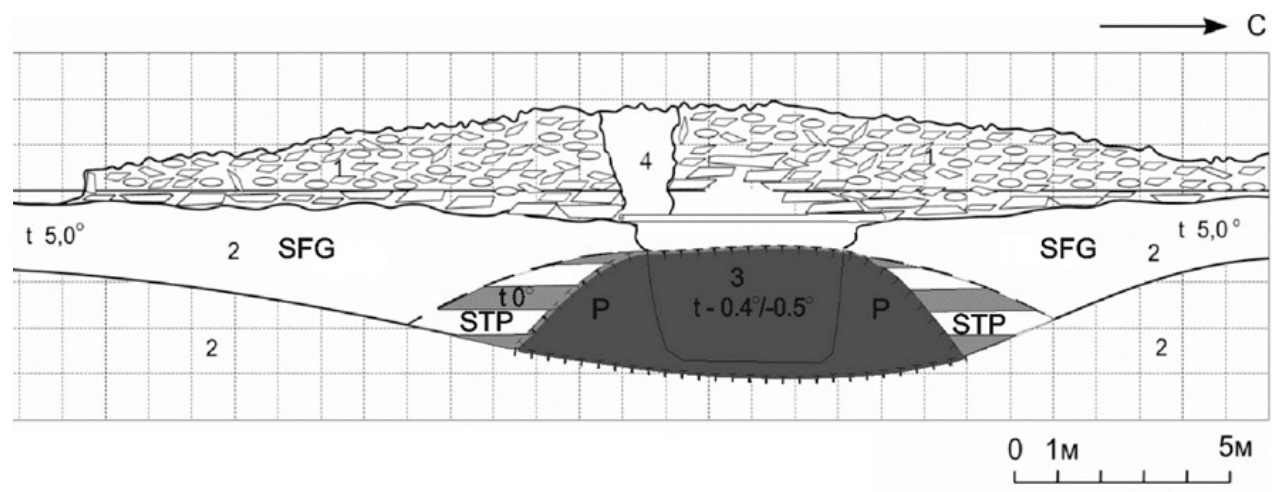

Görsel 4: Kurgan altı permafrost (kalıcı don) olgusunun çizimi (Gorbunov, Samashev, Severski, 2005) 


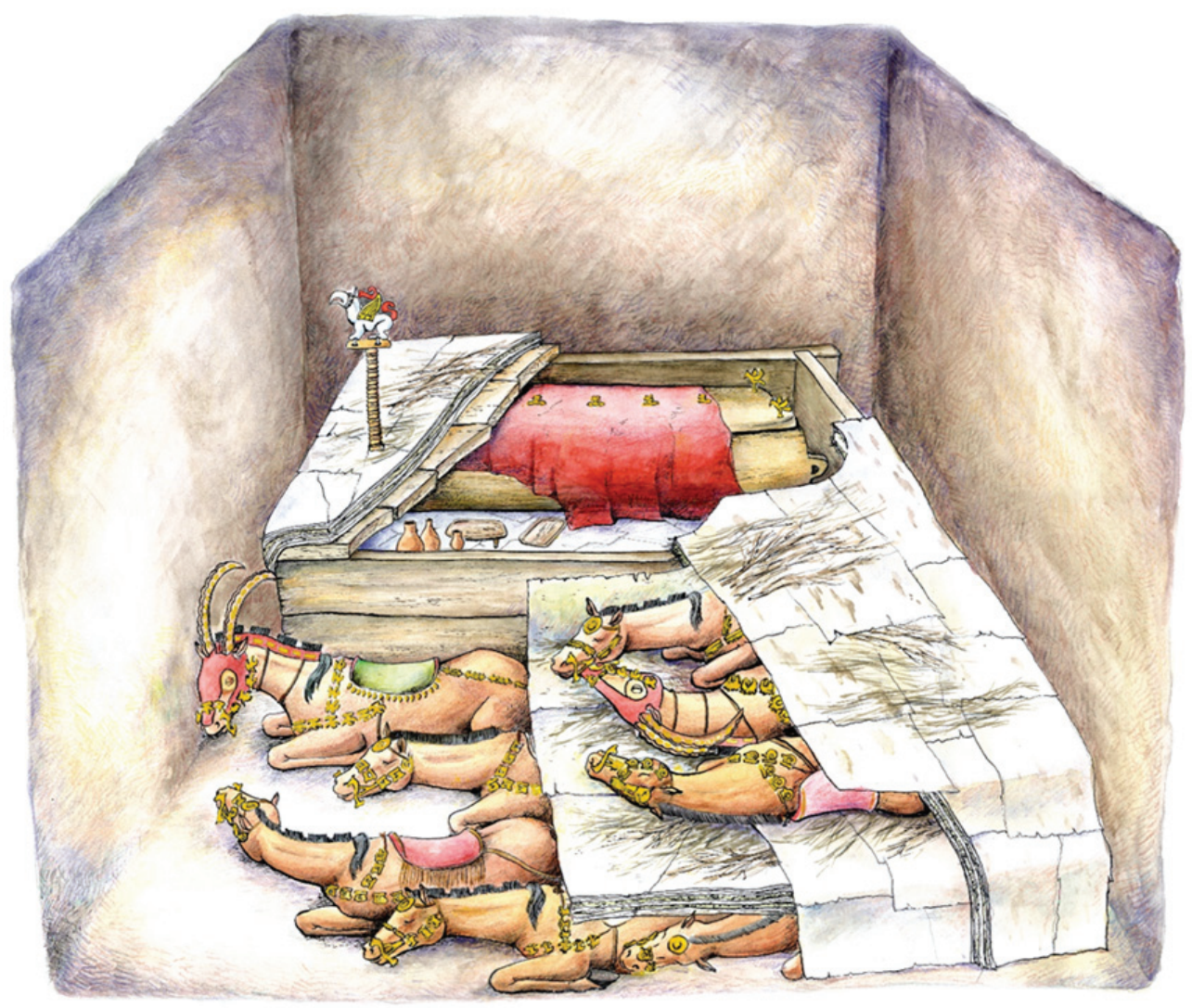

Görsel 3: Berel'deki 11. kurganının restitüsyonu. Z. Samashev, 2011.

Berel kurganlarında yürütülen jeokriolojik incelemeler sonucunda deniz seviyesinden 1000-1500 metre yükseklikte bulunan mezarlıklarda permafrost olgusunun sadece Berel, Tuyakta, Pazırık ve Başadar gibi 2-2,5 m ve üstü yüksekliğine ve $30 \mathrm{~m}$ ve üzeri çapa sahip taş kurganların altında oluşabildiği anlaşılmıştır. Bununla birlikte Ukok platosu ile Çuya nehrinin yukarısındaki kurgan mezarlıklarında olduğu gibi küçük ve orta çaplı kurganlarda kalıcı don tabakasının oluşması için kurganların deniz seviyesinden 2000 metre yükseğinde olması gereklidir (Shulga vd.,2016: 272).

\section{Kurganların tipolojisi}

Z. Samashev, Berel'de kazılarını gerçekleştirdiği kurganların büyüklüğü, yer üstü ve mezar içi yapısal özellikleri, karmaşıklığ 1 ve defnedilenlerin sosyal statüsüne ilişkin diğer göstergeleri göz önünde bulundurularak kurganları 5 tipte sınıflandırmıştır.

1. tip kurganlar, elips veya oval planlı taş örtülerine sahiptir. Ayrıca derin mezar çukurunun güneyine konumlandırılmış ahşap defin odalarına ve odalara konulan tek parça 
kalın karaçam gövdesinden oyulan lahitlere sahiptir. İnsanlar başları doğuya dönük yatırılmış olup onlara üst üste iki, üç veya dört sıra oluşturan bacakları bükük vaziyette karın üstü yatırılmış at cesetleri eşlik etmektedir. Bu tür kurganlarda törensel koşum ve eyer takımlarına sahip atların sayısı 4'ten 17'ye kadar ulaşmaktadır. Buna örnek olarak 1., 4., 8., 9., 10, ve 11. kurganlar verilebilir. Z. Samashev, 1. Kurganı bu gruba günümüzdeki vaziyetindeki biçiminin elipse benzerliğinden dolayı şartlı olarak dahil ettiğini vurgulamaktadır. Bunun nedeni olarak 1. kurganda daha önceki kazıları yürüten hem Radloff'un hem de Sorokin'in çalışmalarında kurganın yapısal özelliklerinden bahsedilmemesi gösterilmektedir (Samashev, 2011:114). 1. tip kurganlar toplumun seçkin sınıfına yani üst tabakasına ait bireyler için inşa edilen yapılardir.

2. tip kurganlar, mimari açıdan dairesel biçimli taş üst örtüye sahiptir. Tıpkı 1. tip kurganlarda olduğu gibi mezar çukurunun güney duvarına konumlanmış ahşap mezar odalarına konulan tek parça karaçam gövdesinden oyulan lahitlerdeki definleri ve atların odanın kuzey kısmına konumlandırıldığı kurganlar bu sınıfa girmektedir. Lakin ilk tipten farklı olarak ahşap mezar odası ile at gömüleri arasında onları birbirinden ayıran bölme veya ahşaptan bir düzeneğin mevcudiyeti söz konusudur. Buna örnek 16., 18. ve 19. kurganlardır. Bu tip kurganlardaki atların sayısı 4'ten 8 kadar ulaşmaktadır (Samashev, 2011:115).

İnsan ve at cesetlerinin arasına temsili duvarın örülmesi, onların ahşap kalkanla ayrılması veya insanlarla atların farklı seviyelere konularak ayrılması Altay Dağlarındaki Göktürk dönemi kurganlarında yaygın olarak karşımıza çıkmaktadır. Örneğin Üstut 12 mezarlığındaki 29. kurganda Göktürk kurganında insan ve at definlerinin arasına taştan küçük bir duvar örülmüştür (Kubarev, 2005:211).

3. tip, ise, küçük çaplı dairesel planlı bir dizi kurganlar ile ilişkilendirilebilir. Bu tip kurganlarda ahşap lahde insan bedenlerinin konulduğu, mezar çukurun kuzey kısmında başları tek veya zıt yönlere çevrilmiş bir veya iki atın defnedildiği kaydedilmektedir (Samashev, 2011:115). Atların başlarının tek (doğu) veya zıt (doğu ve batı) yönlere konulması Göktürk dönemi kurganlarında yaygın görülür.

4. tip, ise plan olarak hafif oval veya eliptik özellik gösteren 36. kurgan için önerilmiştir. Bu kurganı önemli kılan özellik, ahşap lahidin iri kayrak taşlardan oluşturulan taş bir defin odasının içine konumlandırılan 3 sıra geniş kalastan yapılmış olmasıdır. At ise mezar çukurunun kuzey kısmında taş duvarın arkasına başı taş bir desteğin üzerinde hafif kalkık durumda konulmuştur. Mezar odasının tamamı iri taş bloklarıyla doldurulmuştur (Samashev, 2011:115). 36. kurganı diğerlerinden farklı kılan diğer bir özellik ise atın koşum ve eyer takımı süslemelerinin Pazırık kültüründe yaygın olan ahşap malzemeyle değil Maral geyiği boynuzundan oyulmuş olması (Samashev, 2018) ve insan defnine nazaran mezar soyguncuları tarafından fark edilmeden özgün haliyle günümüze ulaşabilmesidir.

5. tip dairesel biçimli ve küçük çaplı 23. kurgandan oluşmaktadır. Bu kurgandaki insan iskeleti mezar çukurunun tabanına yatay şekilde konumlandırılmış taş bir lahdin içerisine konulmuştur ve bu özellik bu kurganı Doğu Kazakistan'ın Kulajurgin ve Dağlık Altay’ın Karakoba kültürlerine yaklaştırmaktadır. Bu kurganın ikinci gruptaki izole edilmiş 
konumlanma pozisyonu, kurgan boyutlarının küçüklüğü ve zengin olmayan buluntuları, mezarın daha geç dönemde inşa edildiğine, kişinin farklı kültür mensubu olduğuna veya düşük sosyal statüsüne işaret ettiği düşünülmektedir (Samashev,2011:115). Kimi araştırmalar tarafından Pazırık kültürü kapsamında ele alınan Karakoba tipi taş tabutlu kurganlar bazı araştırmacılar tarafından ayrı bir Hun kültürü olarak ele alınmaktadır (Surazakov, 1989).

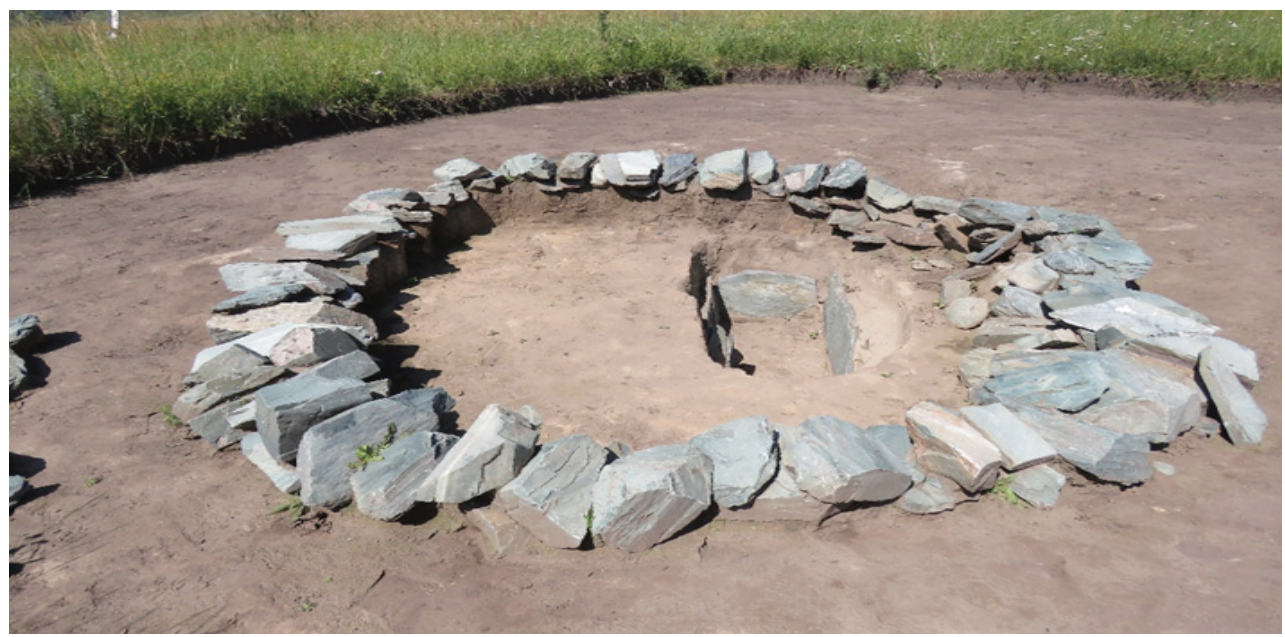

Görsel 5: Hun- Hsiyen-pi dönemi kurganları, III. Grup (2019)

Kurgan tipolojilerine göre Berel'de farklı dönemlere tarihlenen kurganların bulunması Altaylar'da yaşamış çeşitli Proto-Türk boylarının neredeyse çok az farkla adeta "değişmeyen" ölü gömme geleneklerini sürdürdüğünü göstermektir. Pazırık döneminden sonraki Hun ve Göktürk dönemine tarihlenen kurganların aynı ihtişama sahip olmamasının bazı nedenlerini belirtmek mümkündür. Öncelikle Hun dönemiyle Göktürk döneminde Berel bölgesi devletin merkezi konumunda olmayıp, Ordos ve Noin-Ula'daki Hun Şanyü'lerinin ve Ötüken merkezli Doğu Türk Kağanlığıyla Güney Kazakistan'daki Batı Türk kağanlıklarının merkezlerinden uzak bir mesafededir. Diğer bir neden ise doğal olarak deniz seviyesinden en az $2000 \mathrm{~m}$ yükseklikte ve belli büyüklüğe sahip kurganların altında oluşabilen permafrost tabakasının olmaması organik malzemeler ve objelerin korunmasını mümkün kılmamaktadır. Ayrıca mezar soyguncularının verdiği tahribat kurganların özgün halini öğrenmeyi engellemektedir. Yine de Pazırık döneminde olduğu gibi Hun ve Göktürk dönemi kurganlarına defnedilen kişilerin askeri teçhizat ve silahlarıyla, atların ise at koşum ve eyer takımlarıyla birlikte defnedilmeye devam edilmesi kültürel sürekliliğin işaretidir. Altayları mesken edinen ProtoTürk boylarının kim olduğu konusunda bölgeyi anlatan ilk yazılı kaynak olan Çin kayıtları, M.Ö. 206- MS.201 arası dönemde Güneydoğu Altay dağları, Baykal gölü ve İrtiş nehri civarında Ting-Ling boylarının yaşadığını belirtir (Taşağıl, 2017: 13-26). Kanaatimizce Altay'larda Pazırık ve sonraki kurganları bırakanların Proto-Türk boyu Ting-Lingler olduğu en güçlü olasıllktır. 


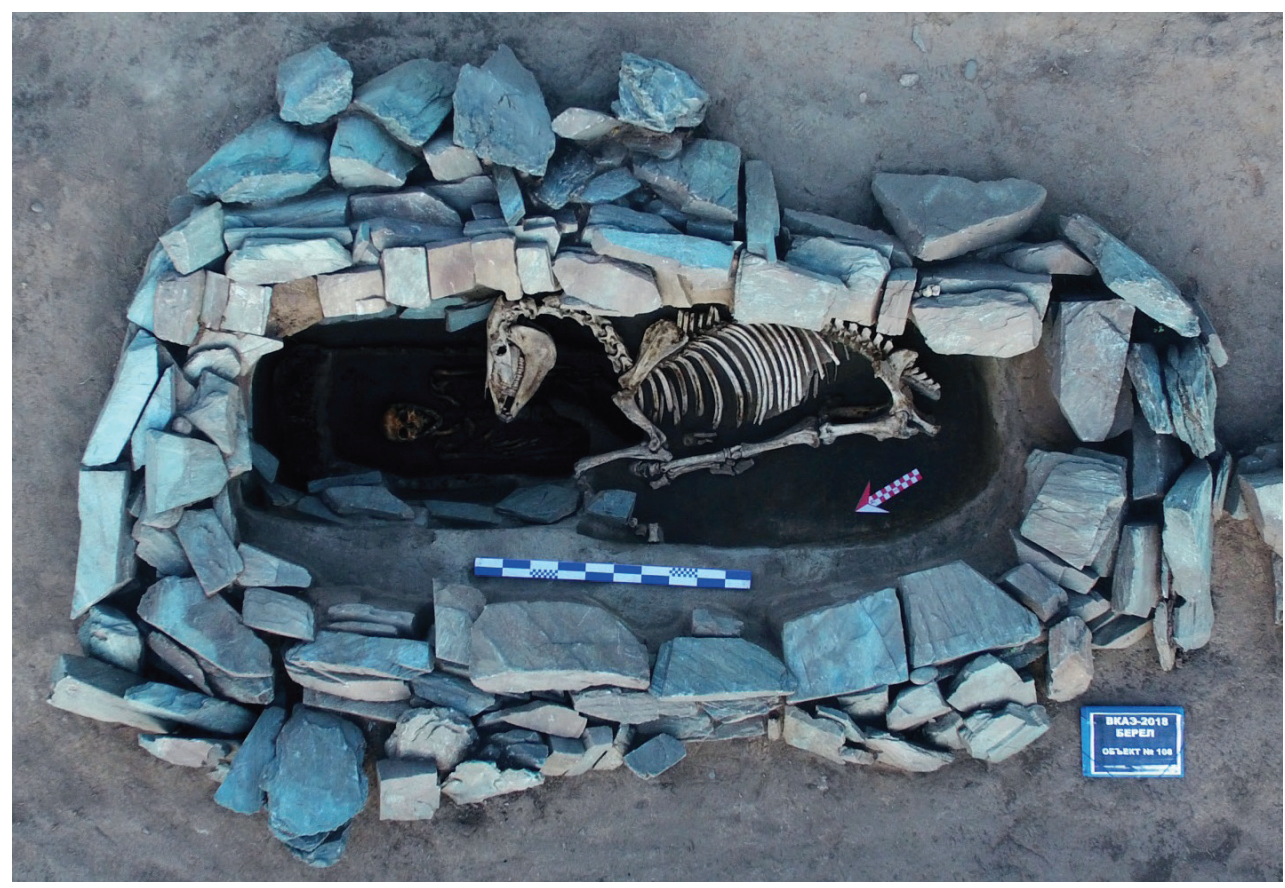

Görsel 6: 108. Kurgan. Hun-Hsiyen Pi dönemi (Samashev vd., 2018)

Pazırık kültürünün tanımı genellikle ölü gömme geleneği bağlamında ele alınmaktadır. Kültürü tanımlayan karakteristik özellikler ise kurganların kuzey-güney ekseninde düz bir zincirleme çizgi oluşturacak şekilde sıralanması, kurganların üst örtülerinin taş malzemeyle oluşturulması, kurganların tam merkezine kare veya dikdörtgen planlı tek ve derin bir mezar çukurunun kazılması sayılabilir. Bununla birlikte en ayırt edici özelliklerden biri mezar çukurunun dibinde ahşap tomruk veya kalaslardan defin odasının inşa edilmesi ve bu odanın kuzey duvarı boyunca at gömülerinin bulunmasıdır. İnsan cesetleri genelde ahşap lahit içine veya döşeklerin üzerine ayakları hafif bükük bir şekilde sağ yanına ve başları doğu yönüne dönük şekilde yatırılmaktadır. Cesetlerin bel hizasında kemer tokaları gibi unsurlar, daha aşağıda kemere kayışlarla sabitlenen ve belirli stilistik özelliklere sahip hançer, kılıç, balta ve ayna (kadınlarda) gibi gereçler ile ayak hizasında ok uçlarına rastlanır (Kubarev\&Shulga, 2007:12). Söz konusu tanımlama daha çok hükümdar, boy beyleri ve soyluların kurganları için geçerlidir. Bununla birlikte Pazırık kültürünün en ayırt edici özelliklerinden biri at koşum ve eyer takımlarını bezeyen hayvan tasvirli üslupta yapılan heykelcik, figürin, levha gibi süslemelerin ahşap malzemeden yapılması ve yaprak altınla sarılmasıdır (Görsel 7).

Altaylar'da "hanedan" kurganları olarak tanımlanan büyük kurganlar ile Berel'deki büyük kurganların (1., 2., 10., 11. ve 36. Kurganlar) mimari özellikleri ve buluntularının büyük ölçüde benzerlikleri nedeniyle aralarında yakın ilişki bulunduğu tespit edilmiştir. Bundan dolayı Berel'in özellikle M.Ö. I. binyılın ikinci yarısında Altay'lardan Karadeniz'in 
kuzeyindeki düzlüklere kadar yayılan geniş coğrafyalarda yaşadıkları kabul edilen İskit/ Sakaların önemli merkezlerinden biri olduğu düşünülmektedir. Böylece Berel'in Altaylarda ilk tespitleri Pazırık kurganlarıyla yapılan ve "Pazırık Kültürü" olarak adlandırılan ortak maddi kültür unsurlarına sahip ve ortak ölü gömme geleneklerini gösteren atlı göçebe topluluklara ait bu medeniyetin Doğu Kazakistan'daki bir devamı veya temsilcisi olduğu ortaya çıkarılmıştır. Bununla birlikte Berel'deki ölü gömme geleneğindeki bazı cesetlerin sırt üstü yatırılması gibi etnografik farklılıklar ile bazı süsleme unsurlarının görünüm ve üretim özelliklerinde farklılıklar da görülmektedir. Bundan dolayı Berel'in Pazırık kültürünün devamı niteliğinde olduğu ancak söz konusu farklılıklar nedeniyle yerel bir boyutu da yansıttığı düşünülmektedir (Samashev,2011: 11).
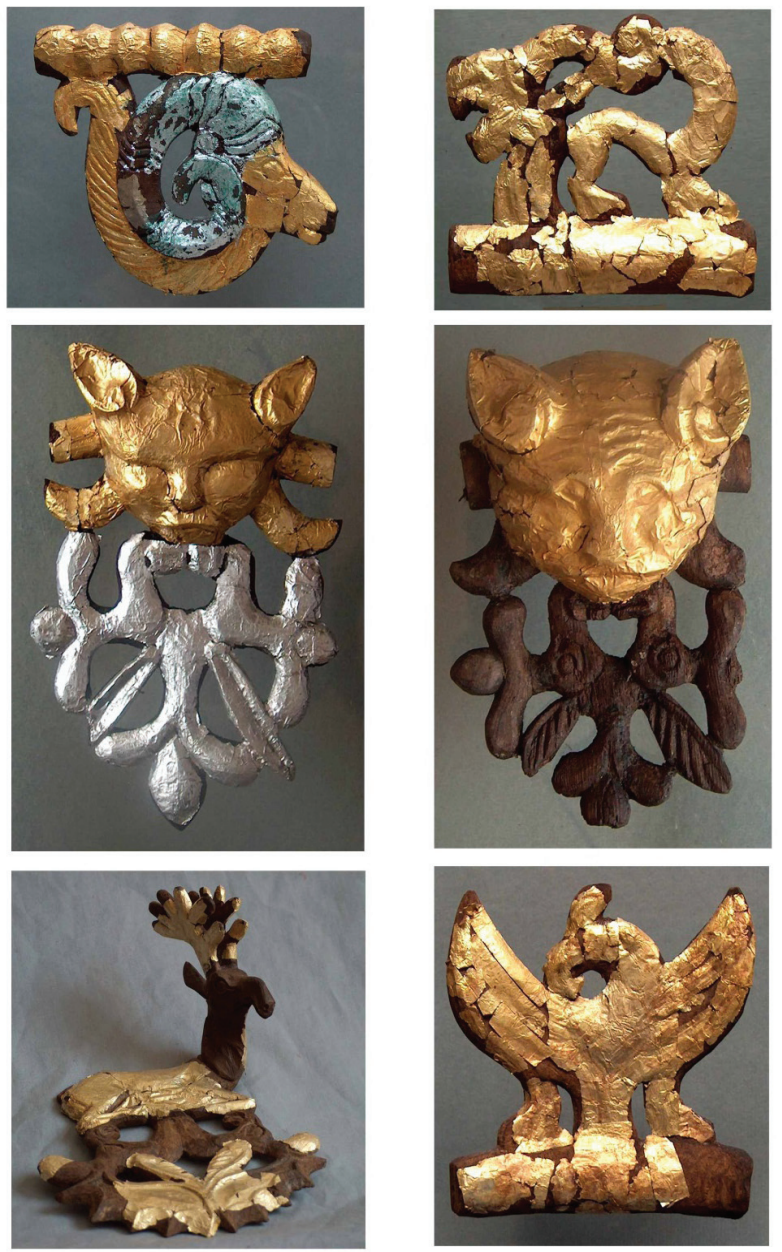

Görsel 7: Hayvan tasvirli üslupta yapılan at koşum takımı süslemeleri. (Z.Samashev, 2011). 


\section{Buluntular}

W. Radloff'un 1865 yılında Berel'de yaptığı kazı ve araştırmalarda tespit ettiği buluntularla ilgili yayınlamış olduğu kitabında çok az bilgi bulunmaktadır. 1. Kurgan dışında kazı yapmış olduğu diğer kurganların hepsinde at defni bulunduğunu, kurganlardan birinde 5 adet atın olduğunu ve atların defnedilen insan bedenlerinden $1,5 \operatorname{arşın~}(1 \operatorname{arşın}=0,71 \mathrm{~m})$ daha yüksekte olduğunu kaydetmektedir. Başlıca buluntuların demirden üretilmiş gemler, çok iyi yapılmış seramik çömlek, kınlı hançer, Tunç çağı örneklerine benzer olan fakat demirden imal edilen ve sapları altın plaklarla kaplı bıçak ve hançerden oluştuğunu yazmaktadır. Ayrıca, W. Radloff, bir cesedin yanında Tunç çağı hançerlerine benzeyen ancak demir saplı ve halkalı uzun bir kılıç bulduğunu ve büyük ihtimalle deri parçasına sabitlenmiş, $5 \mathrm{~cm}$ uzunluğunda, dikdörtgen biçimli demir zırh parçalarını tespit etmiştir (Radloff, 1989:451). 1959 yıllında 1. Berel kurganının kazısını yeniden gerçekleştiren S. Sorokin, Radloff'un tanımlamalarını temel alarak kurganının çiziminin yapmış (Görsel 8, 9) ve kazı buluntularını tanımlamıştır (Sorokin,1969:216). Radloff, kazı buluntusu olarak yayınladığı demir kılıç, hançer, bıçak ve demir zırh parçalarının hangi kurgandan geldiğini belirtmemişse de kurganların konumu ve içeriği dikkate alındığında zırhın Hun- Hsiyen Pi kurganlarından olduğunu tahmin etmek mümkündür.
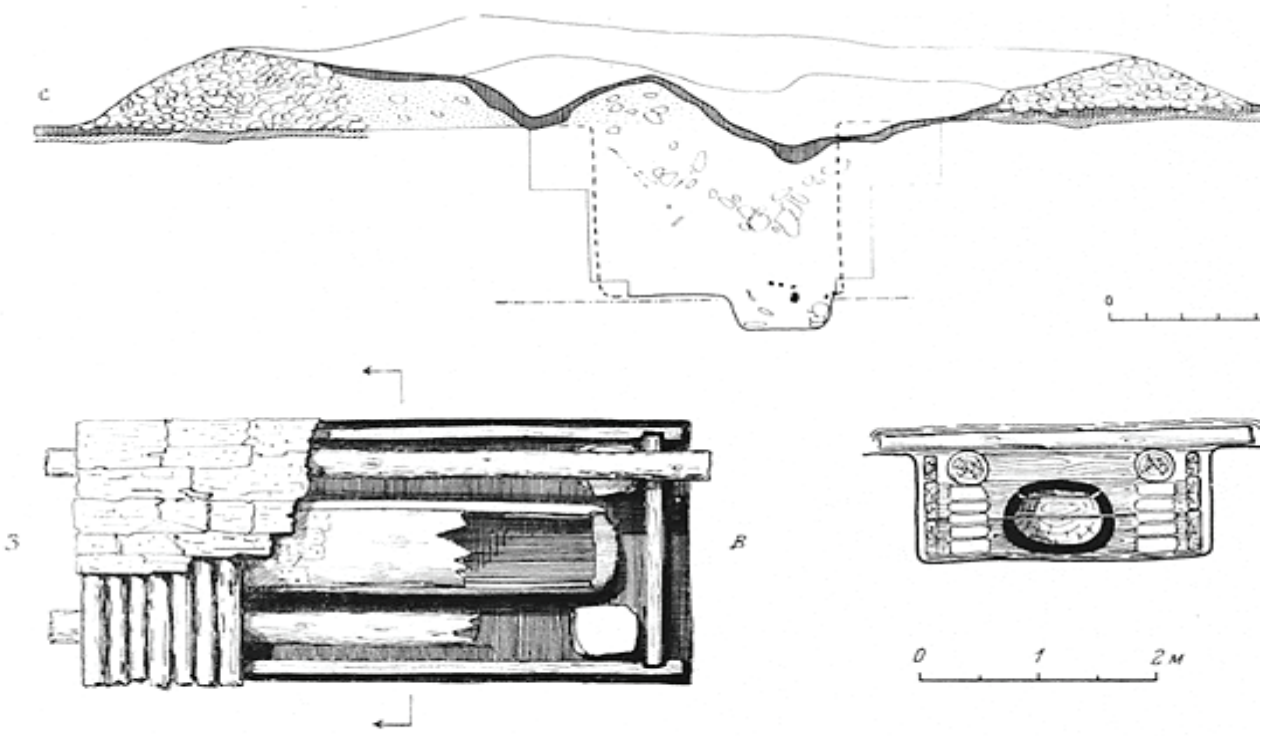

Больної Берельский курган. Разрез и реконструкиия камеры но даниям расконок 1865 и $1959 \mathrm{rr}$.

Görsel 8: Berel'deki 1. kurganın kesit çizimi ve restitüsyonu. (Sorokin,1969) 


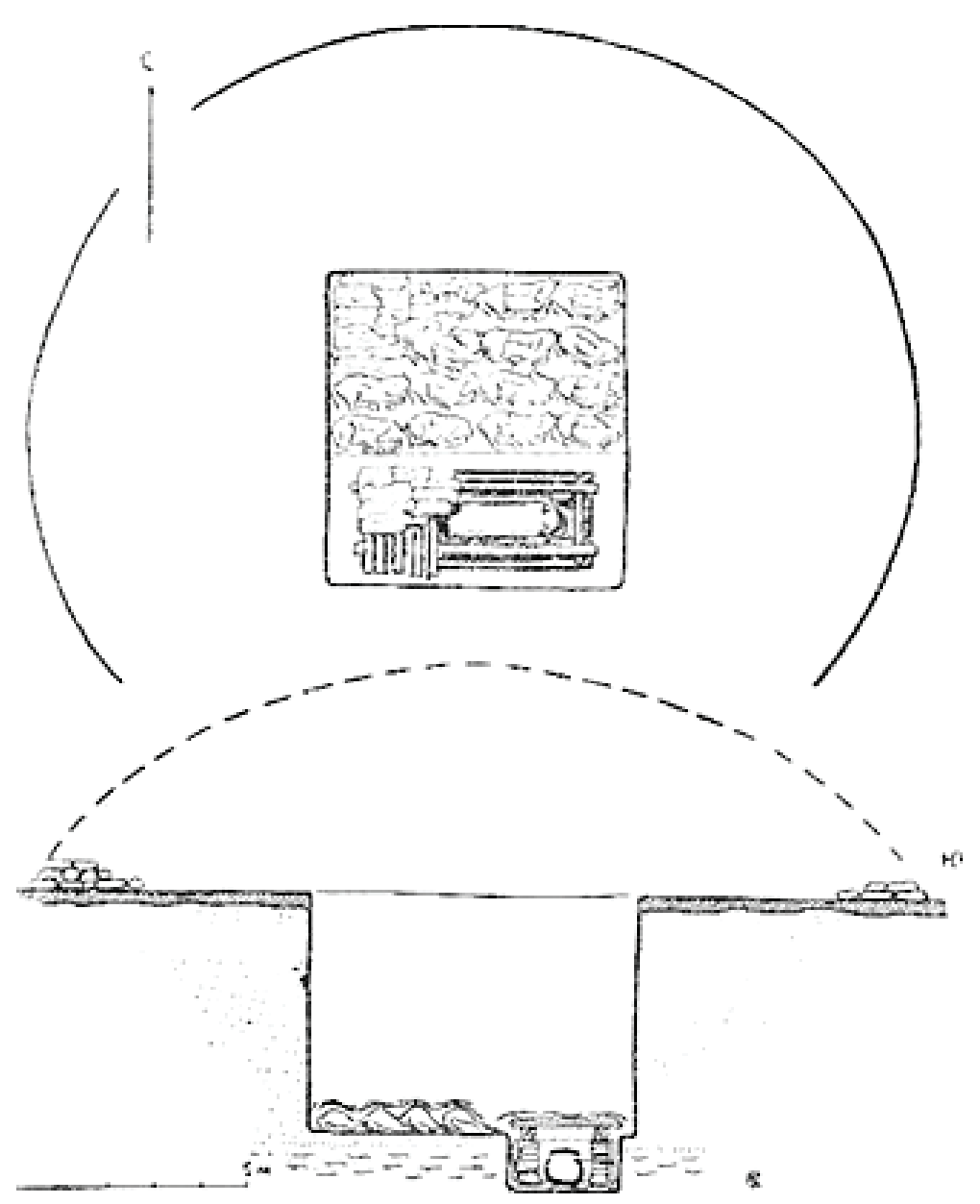

Görsel 9: Berel'deki 1. kurganı ve mezar odasının çizimi (Sorokin, 1969)

İskit/Saka kurganlarına defnedilen soyluların giyim kuşamı Altaylardaki Pazırık, Ak Alaha gibi kurganlarındaki permafrost özelliği sayesinde iyi korunabilen buluntulardan oldukça iyi bilinmektedir. Eldeki verilere göre, Berel'deki İskit/Saka dönemi kurganlarında bulunan soylulara ait giyimlerde demir zırh parçalarıyla kaplama uygulaması yoktur.

Altay'daki kurganlarının Çarlık Rusya'sının yayılmacılığı ve işgali sırasında mezar soyguncuları tarafından yağmalandığı Miller ve Messerschmidt gibi araştırmacılardan iyi bilinmektedir (Miller, 1937:524, Radlov, 1989:417-418). Bu tür soygunların sonucunda Berel kurganlarının permafrost 1sı dengesinin bozulmasının yanısıra hükümdarlara birlikte defnedilen prestijli objelerin ve silahların çalınması sürecinde bazı küçük parçalar dışında giyim kuşamların tamamen yok edildiği saptanmıştır. Soyguncular öncelikle altın ve gümüş gibi değerli metallerden üretilen eşyaları hedeflediği için araştırmacıların eline çoğunlukla permafrost tabakaları sayesinde iyi korunabilen mitolojik hayvanlar biçimindeki yaprak 
altınla kaplı levha ve apliklerle süslenmiş ahşap ve geyik boynuzu gibi malzemelerden üretilmiş ihtişamlı at koşum ve eyer takımlarına ait buluntular geçmiştir (Samashev, 2013: 123-124).

Berel Kurganlarında, eyer ve koşum takımları dışındaki buluntular yapılmış oldukları malzeme ve işlevsel özellikleri bakımından oldukça çeşitlidir. Buluntular malzeme bakımından genellikle altın, kalay, tunç, gümüş, demir gibi metal; karaçam ve huş ağacı gibi ahşap, yün kumaş, kürk parçaları ve keçe gibi tekstil; kemik, taş, boynuz, deri, seramik vb. olmak üzere oldukça farklılıklar göstermektedir.

Berel kurganlarındaki buluntular işlevsel özelliklerine göre aşağıdaki şekilde gruplara ayrılmıştır: törensel-ritüel eşyalar, giyimler, gündelik araç gereçler, (silahlar), atların koşum takımlart.

Törensel-ritüel eşyalar: Üst düzey yönetici ve soylu elitlerin yaşamları veya iktidarlarıyla ilgili nesnelere yani iktidar sembollerine 11. kurganda bulunan grifon heykelciğini ve lahit kapağı üzerine çakılmış olan dört adet altın kaplanmış bronz çivilerin üzerinde bulunan uçar ve konar kompozisyonda tasvir edilmiş grifon figürleriyle sapı mitolojik hayvan şeklinde oyulmuş olan bir kamçı bu sınıfa dahil edilmiştir. Ayrıca, bu kategoride pratik işlevi olmayan ve muhtemelen dini törenlerde kullanılan 4., 10. ve 11. kurganlarda bulunan dağ tekesi boynuzlarıyla taçlandırılmış 5 çift at maskesi de yer almaktadır (Samashev, 2012:197-199, Kutlu, 2020e: 67).

Giyim: Berel Kurganlarında, ne yazık ki tamamen korunmuş giyim unsurları ele geçmemiştir. Giyim unsurları, 9., 11., 16., 31. ve 34. kurganlar olmak üzere sadece beş kurganda saptanmıştır (Dzhumabekova vd., 2010:307-309). Bunlar yün ipliklerden örülmüş çok renkli bir kıyafet, halı, deri ve kürklerin kalıntıları küçük parçalar halinde ve aralarında turkuaz boncuklarla süslenmiş bir giyim parçasıdır. 31. kurganda altın levhalıklarla süslenmiş sivri uçlu bir erkek başlığı kalıntısı bulunmuştur ve rekonstrüksiyon çalışmaları henüz tamamlanmamıştır (Samashev, 2011:29).

Günlük yaşam araç gereçleri: Bu buluntu grubu, seramik kaplar, günümüz Kazak toplumunda "astau" olarak adlandırılan genellikle et yemeklerinin servisinde kullanılan ahşap dikdörtgen biçimli tabaklar ve ayakları sökülüp takılabilen küçük bir masa, Yak öküzü boynuzundan yapılmış bir kap, boyaları ögütmeye ve tahılları ezmeye yarayan taş eşyaların yanısıra kurgan inşası esnasında kullanılan ahşap kürek, çekiç, ahşap direk, buz keski, takozlar, çırpıcılar, sıyırıcılar ve ahşap merdiven gibi araç gereçlerden oluşmaktadır (Samashev, 2012: 197-199).

At koşum takımları: Berel'deki kurganlara defnedilen atlara ait buluntular arasında yer alan eyer ve koşum takımları önemli bir yer tutmaktadır. İskit/Saka döneminin karakteristik özelliklerini yansıtan koşum takımları, tepe, alın ve burun kayışlarından oluşmaktadır. Ağızlıklar/gemler genellikle demirden imal edilmiş lakin az sayıda bronz örnekler de ele geçmiştir. Diğer yandan at maskesi, perçem kılıfı, atların yele ve kuyruk kesim şekilleri ve kaplamaları işlevsel açıdan sadece ritüel ve törensel eylemlere yönelik olmalıdır. Alçak ve yüksek kabartma tekniğiyle yapılmış at eyer ve koşum takımını bezeyen kalay ve yaprak 
altınla kaplı ahşap süslemelerde daha önce kullanılmışlığa dair herhangi bir yıpranma izlerine rastlanılamamıştır (Samashev \& Mylnikov, 2004:210) Böylece bu süsleme unsurlarının cenaze törenine özel hazırlandıklarına veya ölümden sonraki hayatta kullanılmak üzere yapıldığına dair bir inanca işaret etmektedir.
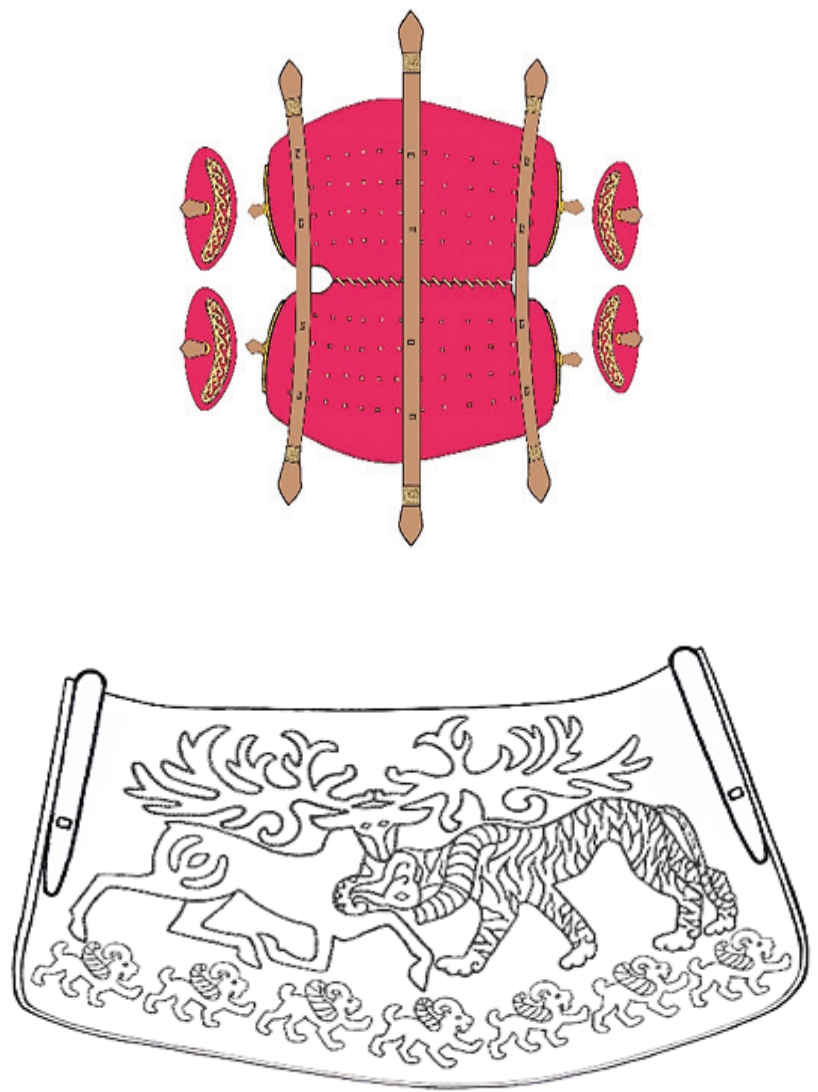

Görsel 10: Pazırık tipi yumuşak yastıklı, kaşlı eyer ve keçe örtüsü restitüsyonu. (Z. Samashev, 2011)

Pazırık tipi eyer takımları: Günümüzde Çin Halk Cumhuriyeti’nde bulunan Doğu Türkistan'daki mumyalanmış insan cesetleriyle dikkat çeken Subaşı kurganlarındaki eyer takımıyla yapısal açıdan çok büyük benzerlik göstermektedir. Subaşı kurganlarındaki Pazırık tipi eyer takımlarının benzerlerini Çin Büyük Piramidi olarak adlandırılan büyük kurgandaki terakota askerlerinin atlı savaşçı tasvirlerinde de görülebilmektedir. Bu paralelliklerden ötürü Prof. Dr. Zainolla Samashev, Pazırık kültürünün daha da doğuya kadar yayılmış olabileceğini ve terakota ordudaki atlı savaşçıların paralı göçebe askerlerini betimleyebileceğine düşünmektedir (Samashev, 2013:622). Bu tespite terakota askerlerin arasındaki süvarilerin eyer takımlarını inceleyince aynen katılmaktayız. 


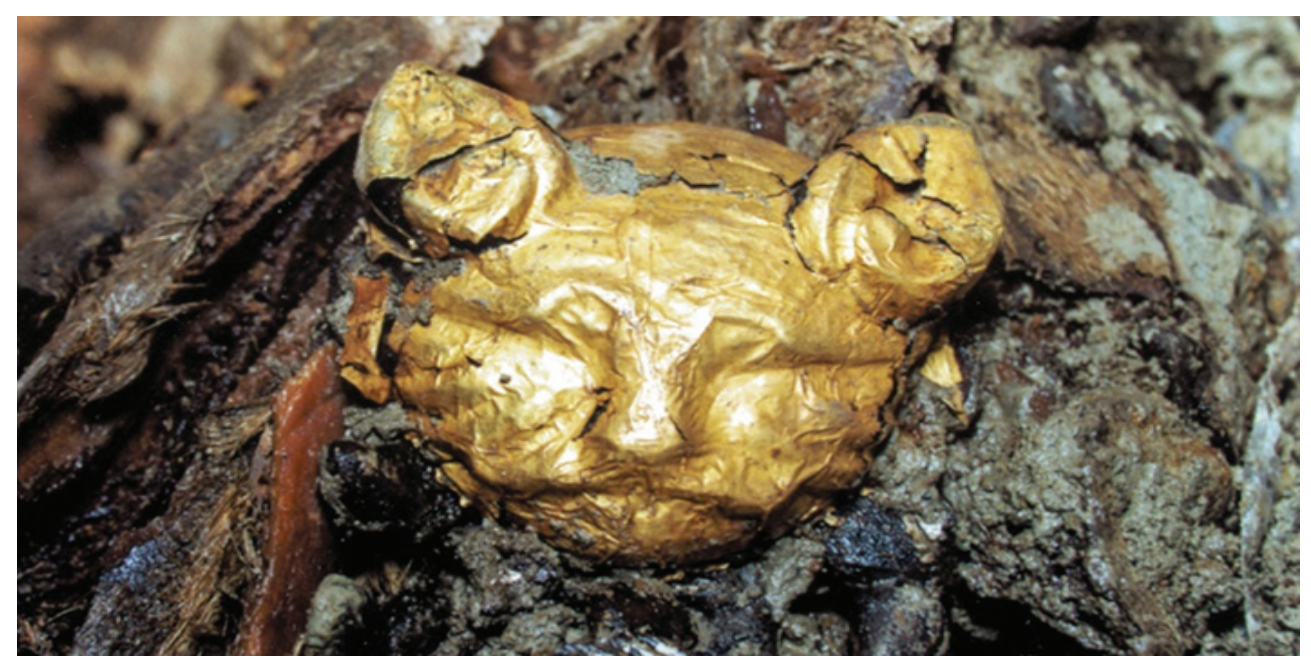

Görsel 11: At koşum takımını süsleyen kedigil avcı figürini. In situ. Z. Samashev, 2011

Berel Kurganlarında yapılan kazılardan elde edilen giyim, silah, at koşum ve eyer takımları süslemelerinde büyük çoğunlukla hayvanların ve bazı mitolojik varlıkların tasvir edildiği özellikle belirtilmelidir (Görsel 10). Kaplan, İlbis (kar barsı) gibi kedigil yırtıcılar, geyik, at, kartal, balık, kurt, deve, yaban domuzu, dağ tekesi, arkar (dağ koyunu), tavşan gibi hayvanlar ve grifon, sfenks gibi bazı mitolojik varlıkların mücadele sahneleri betimlenmiştir (Samashev, 2012:207-218). Ayrıca Berel'de ele geçen buluntuların üzerindeki betimlemelerin ikonografik özellikleri Pazırık kültürünün hayvan tasvirli süsleme sanatının tamamıyla eşleşmektedir (Samashev, 2012b:26). Böylesi bir ikonografinin Berel'deki kurganların sahibi olan atlı göçebe toplulukların çeşitli inanç ve dünya görüşlerini yansıttığı düşünülmektedir. $\mathrm{Bu}$ tasvirlerde yer alan simgeler, mitolojik ve efsanevi inançların kaynağını oluşturan kavramların ve bilgilerin aktarımını sağlayan özgün kodlar olarak yorumlanmıştır. Bu dönem sanatına yansıyan ikonografinin kaynağının İskit/Saka toplulukların inanç ve dünya görüşleri olduğu yadsınamaz şekilde açıktır.

\section{Berel'in atları}

Berel kurganlarında şimdiye kadar 60’tan fazla at iskeleti saptanmıştır. Kurganlara defnedilen atların sayısı gömülenlerin sosyal statü ve hiyerarşik konumunu gösteren bir unsur olarak değerlendirilecek olursa Berel'de, Ukok Platosundaki kurganlarının yanı sıra Orta ve Doğu Altayların diğer Pazırık kurganlarının önüne geçecek sayıda at defnedilmiştir. Örneğin: Başadar kurganında 2, Pazırık III. ve Pazırık IV. Kurganlarında 14, Pazırık I Kurganında 10, Pazırık V Kurganında 9, Tuyakta I ve II kurganlarında 8'er adet at defnedilmiştir. Oysa 1. Berel kurganında 17 ve 11 . Berel kurganında ise 13 adet at iskeleti bulunmuştur (Kosintsev \& Samashev, 2014:24). Bu bulgular Berel kurganlarını Pazırık kültürü kurganları arasından özel bir yeri olduğuna işaret etmektedir. 
Atların uzun süre ve yoğun bir şekilde Altaylar gibi dağlık bölgelerde binek ve yük taşıma amaçlı kullanımı Berel'deki atların kemiklerinde kırıklar ve bazı morfolojik bozulmalara neden olduğu anlaşılmıştır. $\mathrm{Bu}$ durum özellikle kemik kalıntılarında tespit edilen intervertebral disklerin ve eklem yüzeylerinin lineer kırıkları, kemik büyümeleri ve ciddi patolojiler, torakolomber omurgaların ankilozan-destruktif değişiklikleri gibi sayısız yaralanma izleri ile kanıtlanmaktadır (Kashkinbayev, 2013:340-341).

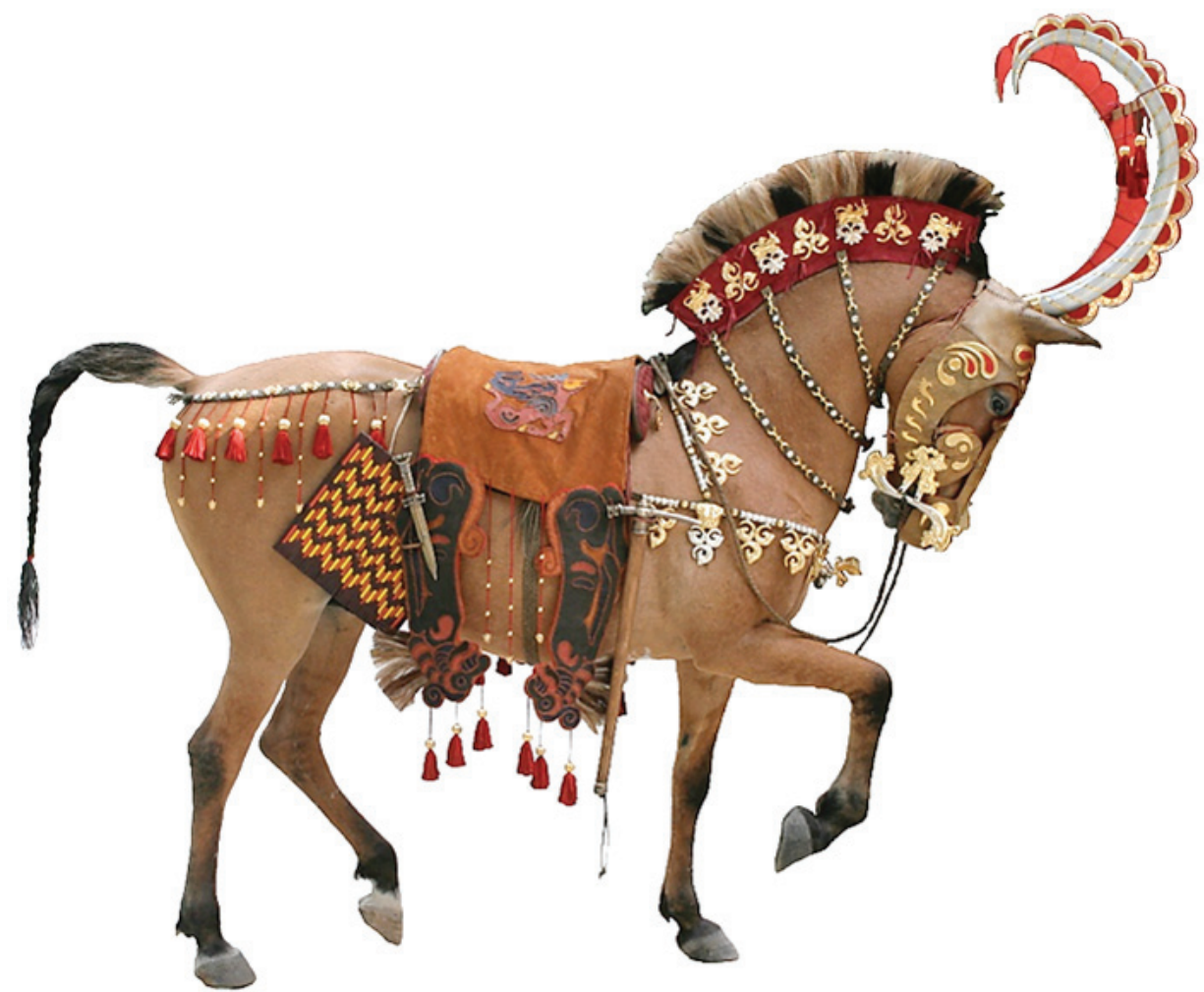

Görsel 12: Törensel maske giydirilmiş Berel Atının rekonstrüksiyonu. Z. Samashev, 2005 K.

Altınbekov restorasyonu.

Atlar, Altaylardaki göçebe toplumların günlük yaşamının vazgeçilmez bir parçası olmasının yanı sıra inanç, dünya görüşü ve ölümden sonraki yaşama dair düşüncelerde kendilerine yer edinmiştir. İnsan ile atı arasında sıra dışı bir bağ ve dostluk hissi oluştuğu için dünya hayatında atsız olunamadığ gibi ölümden sonraki hayatta da atsız olunamayacağ1 şeklinde bir inanç oluşmuştur. Bu durum kurganlara özel eyer ve koşum takımları ve maskelerle süslenen atların sahipleriyle defnedilmeleri uygulamasını ortaya çıkarmıştır. Bu nedenle atlar ölü gömme geleneklerinde de ayrıcalıklı yere sahiptir. Berel kurganlarında atların alın kemiğinin ortasına çekiç benzeri sivri uçlu bir aletle vurularak cansızlaştırılmış ve defnedilmiştir (Kashkinbayev\&Samashev,2005: 61). Kurganlara defnedilen atların 
tamamının erkek olduğu, dişi ve kulunların (taylar) defnedilmediği anlaşılmıştır. Kurganlarda iskeletleri ele geçen atların osteometrik araştırmalarının sonuçlarına göre, neredeyse tamamına yakınının orta yaşlı (10-12yaş) ve yaşlı (18-19 yaş) atlardan oluştuğu kaydedilmiştir. Kazılarda bulunan ve incelenen atların boyları 141-152 cm aralığında değişen ve genetik olarak Asya atları grubuna ait olduğu ortaya çıkarılmıştır (Görsel 12). Bununla birlikte uzmanlar Berel kurganlarındaki atların anatomik ve morfolojik özellikleri bakımından Kazak “Jabı" cinsine benzer olduğunu da saptamıştır (Kashkinbayev,2013: 50, 117-120). Böylece Altay coğrafyasına ve soğuk iklimine uyması şüpheli görünmesine rağmen daha önceki çalışmalarda Pazırık kültürü atlarının Orta Doğu bölgesinden getirilmiş olduğu görüşünün temelsizliği bilimsel olarak ortaya koyulmuştur.

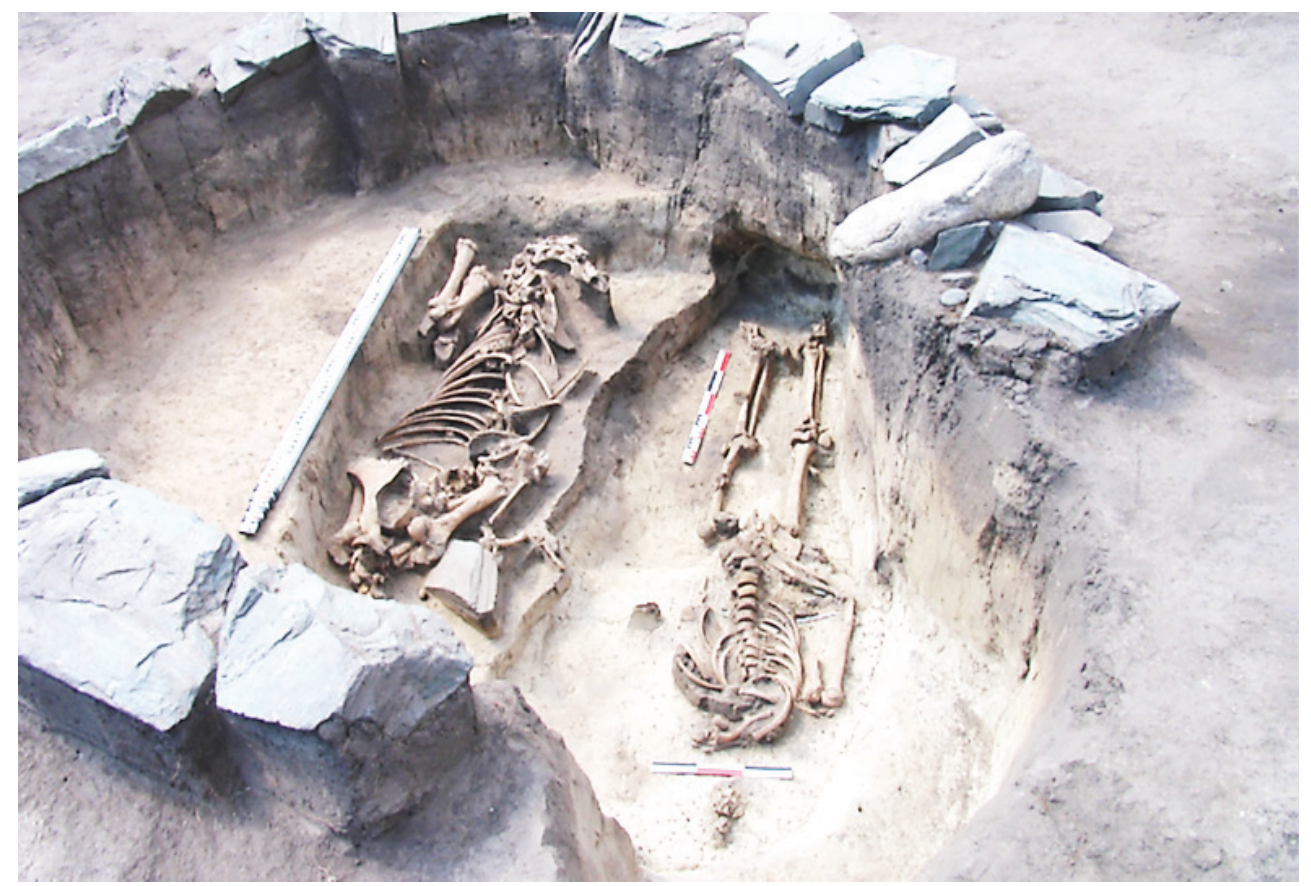

Görsel 13: Berel'deki 16C Göktürk dönemi kurganı, (Z. Samashev, 2011).

Berel'deki Göktürk ve Hun- Hsiyen Pi dönemlerini at buluntuları bağlamında ele alacak olursak onların da Pazırıklılar gibi savaşçılarını silahları, kemer tokaları gibi giyim unsurlarıyla ve at koşum takımlarıyla donatılmış atlarıyla birlikte gömdüğünü görmekteyiz. Arkeozoolojik incelemelere göre Göktürk dönemine tarihlenen kurganlardaki atların cinsiyetleri aygır olup (Görsel 13) Pazırık atlarının iskeletleriyle boyut olarak büyük benzerlik göstermektedir (Samashev,2011: 121).

Berel'deki bazı kurganların üst örtüsünün farklı kısımlarında at kemikleri saptanmıştır. Söz konusu at kemikleri, Herodot (II, 216 ve IV, 72) ve İbn Fadlan gibi kaynakların belirttiği at kurbanı ritüeli ve anma törenleriyle ilişkilendirilmektedir. Burada ilginç olan 
bir başka kültürel süreklilik olgusu ise at kurbanı geleneğine bazı Türk topluluklarında günümüzde dahi rastlanmasıdır. Örneğin Afganistan'da yaşayan Kazaklarda ve Rusya Federasyonu'ndaki bazı Türk soylu Altay halklarında, ata mezarlarına kurban edilen atların derisinin ve uzuvlarının asılması geleneği günümüze kadar uygulanagelmiştir (Samashev vd.,2017: 154-155). Ayrıca bu nokta en dikkat çekici örneklerden bir diğeri ise Türkiye'de karşımıza çıkmaktadır. Çorum’un adını bir Oğuz boyundan alan ilçesi Dodurga'da Mehmet Dede Türbesinin yanında her yıl düzenlenen yağmur duası geleneğinde at kurbanı ritüelinin uygulandığı görülmektedir (Üren, 2015: 73).

Berel'in Pazırık dönemi kurganlarında tespit edilen ortak özellikler ise, "sayıları 1 -17 arasında değişen sayıda atın defnedilmesi, ahşap mezar odasının içinde konumlandırılan tek parça karaçamdan oyulmuş veya taştan yapılan lahitlere konulan insanların başları doğuya dönük, bedenleri sırt üstü yatırılmış şekilde defnedilmesidir. Bununla birlikte mezar odalarına koyun etinden yiyeceklerin, silah, günlük kullanım eşyaları ve diğer ev gereçlerinin konulması" da tespit edilen ortak özelliklerdendir (Samashev, 2011b: 220). Berel'deki Pazırık, Hun, Hsiyen-Pi, Erken Türk ve Göktürk dönemi kurganlarında görülen ortak özellik ise atlı ölü gömme geleneğinin devam etmesi ve cesetlerin başlarl doğu yönünde sırt üstü yatırılmasıdır. Ayrıca insanların silah, günlük kullanım eşyaları ve diğer gereçlerle atların ise koşum takımlarıyla donatılarak defnedilmesidir.

Berel kurganlardaki insan bedenlerinin ve at cesetlerinin (hafif sapmalarla) doğuya yönelen bir doğrultuda defnedilmesi ve kurganların hemen doğu yanlarında balbalların konumlandırılması rastgele bir olgu değildir. Güneşin doğuş yönünün bozkır hayatındaki ve ölü gömme geleneğindeki önemi, Orta Asya'da Erken devirlerden itibaren geleneksel konut ve çadırların girişinin doğuya bakması, kurganların ve anıtsal mezar komplekslerinin yanına dikilen bediz ve balbalların doğuya doğru sıralanışından anlayabilmekteyiz. Örneğin, Kazakistan'da M.Ö. 3500'lü yıllara tarihlenen Kalkolitik dönem Botay kültürüne ait konutları girişleri (Kutlu, 2020a:2461-2462), Erken İskit dönemine ait Şilikti, Taldı 2, Eleke Sazı (Kutlu, 2020b:148, Kutlu, 2021: 60) kurganların dehlizlerinin yönü, Altaylardaki Pazırık kültürü kurganlarındaki definlerin ve balbal sıralarının yönü (Shulga\&Shulga,2016: 72-76), Hun konutlarının giriş yönü (Rudenko, 1962: 85), Bilge-Kağan, Koli Çor ve Eleke Sazı Göktürk mezar anıt komplekslerinin törensel yol ve balbal sıralarının dizilişi doğu yönüne göre düzenlenmiştir (Kuzuoğlu \& Gökçek, 2005: 31, Mert, 2015: 266, Kutlu, 2020c: 266).

Bununla birlikte Eski Türklerde ana yönün doğu olduğunu Kaşgarlı Mahmud'un Divan-ü Lugat't-Türk'te yayımlamış olduğu dünya haritasını doğuyu esas alarak çizmiş olmasından görmemiz mümkündür. Ayrıca, Çin yazılı kaynaklarından yararlanan Jean-Paul Roux, Türklerin atası olan T'u-küye'lere (Tiele) göre dünyanın doğan güneşe göre düzenlendiğini, bu nedenle doğunun her zaman "ön” olarak adlandırıldığını, batının ise "arka" olarak tanımlandığını belirtmiştir. Ayrıca Türk Kağanı'nın tahtında oturduğunda sürekli doğuya yönelik oturduğunu, çadırın girişinin ise doğan güneşin yönünde olduğunu belirtmiştir (Roux, 2015: 66). Bununla birlikte renklerin yön belirttiği ve Türk boylarının adlandırılmasında da kullanıldığı anlaşılmaktadır (Pritsak, 1954, 378). Göktürklerin de "Doğu Türkleri” anlamına geldiği “gök” veya "kök” kelimesinin doğuyu ifade ettiği düşünülmektedir. 
$\mathrm{Bu}$ bilgilerin 1şı̆̆ında Berel'deki kurganlara defnedilen insanların, onlara ait atların başlarının doğuya dönük olarak konumlandırması, balbalların (dikilitaş) kurganların doğu kısımlarına dikilmesi şeklindeki uygulamalar Berel'deki ölü gömme geleneğinin Sakaİskitlerden, Hun ve Göktürklere kadar kesintisiz olarak sürdüğünü açıkça göstermektedir.

Berel'de Hun ve Göktürk dönemi mezar anıtlarının tespitinin özgün değeri, Saka/ İskit topluluklarıyla Türk halkları arasındaki akrabalığı kültürel sürekliliğin maddi kültür unsurları ve ölü gömme gelenekleriyle birebir ispatı olarak karşımıza çıkmasıdır. Berel'de tespit edilen materyal kültür, M.Ö. I. binyılda gelişen mevsimsel göçebe hayvancılık yöntemlerinin, hayvansal materyallerle ahşap, metal, taş gibi doğal malzemelerin birlikte kullanımıyla yapılan konutlar, ev araç ve gereçleri, giyim, süs öğeleri; yakın ve uzak dövüş silahları, koruyucu zırh, askeri teçhizat ve at ekipmanları gibi ürünlerin bazı değişim ve gelişmeye uğrayarak Hunlar, Göktürklere kadar ve sonrasındaki Türk toplumlarına kadar ulaşarak devam ede gelmiştir (Samashev, 2011: 172).

\section{Değerlendirme ve sonuç}

Berel'de İskit/Saka döneminden Göktürk dönemine yani Demir Çağından Orta Çağlara kadar büyük ölçüde benzer ölü gömme gelenekleri uygulanarak kurgan şeklinde mezar anıtlarının inşa edildiğinin tespit edilmiştir. Böylece tarihi olarak kültürel süreklilik bağlamında Demir Çağdan Orta Çağa kadar uzanan zaman diliminde Proto-Türk ve Türk halklarının aralarındaki bağ, antropolojik ve arkeolojik verilerle kesin şekilde ortaya çıkmaktadır. Berel Kurganlarında M.Ö. IV-III. yüzyıldan M.S. VIII. yüzyıla kadar yaklaşık on bir asır süreklilik gösteren ancak zaman içerisinde bazı küçük değişim ve farklılıklara rağmen ana karakterini değiştirmeyen kurgana bağlı atlı ölü gömme geleneklerinin varlığı kanıtlanmıştır. Berel'deki kurganların bir boy veya hanedan mezarlığg ş̧eklinde oluştuğu, aynı soy veya hanedana mensup kişilerin yüzyıllar boyunca mezarlarını kendi atalarına ait olarak benimsedikleri eski kurganların yanına konumlandırdıkları anlaşılmaktadır.

Berel'in de içinde yer aldığı Altay kurganları üzerine yapılan bazı araştırmalarda kurganlar genellikle farklı dönemlere ayrılarak ele alınmakta ve dönemler arasında kurgan temelli ölü gömme geleneğinin varlığı ve devamlılığı yadsınmaktadır. Böylece kurgan temelli ve atlı gömü esasına dayanan ölü gömme gelenekleri sadece belirli dönemde (İskit/ Saka: Pazırık) görülmüş ve sonraki dönemlerde kesintiye uğramış algısı oluşturulmaktadır. Ayrıca İskit/Saka toplulukları ve kültürüyle daha sonraki Proto-Türk halkları ve kültürleri arasındaki ilişki dikkatlerden kaçırılmaya çalışılmaktadır. Bu nedenden dolayı arkeolojik ve antropolojik veriler bilimsel yöntemlerle değerlendirilmeli; dönemler arası kültürel süreklilik olgusunun varlığı veya yokluğunu yadsınmamalıdır. Bu çalışma Berel kurganları bağlamında Demir Çağdan Orta Çağ’a kadar uygulanan ölü gömme gelenekleri ve kurgan şeklindeki mezar anıtlarının mimari özelliklerini değerlendirerek yeni bir yaklaşım ortaya koymayı amaçlamıştır. Güncel ve bilimsel yeni bilgiler, Berel Kurganları örneğinde İskit/Saka topluluklarıyla Proto-Türk ve Türk halkları arasındaki kültürel bağ ve süreklilik olgusunu açıkça ortaya koymaktadır. 


\section{Notlar}

1 İskit/ Sakaların ve özellikle Pazırık kültürünün etnik aidiyeti uzun yıllar boyu tartışmalı bir konu iken son yıllarda yapılan arkeolojik, antropolojik ve genetik çalışmalar Hint-Avrupalı kökenden ziyade Orta Asya'nın yerli Türk halklarıyla bağını ortaya koymaktadır. Bu çalışma kapsamında İskit/ Sakaların ölü gömme gelenekleri ve kurgan kültürü açısından kendilerinden sonraki Orta Asya Türk halklarıyla bağının kültürel süreklilik olgusuyla kesin olarak bilimsel verilerle kurulabilmesine dayanarak İskit/Sakaların Proto-Türk oldukları anlaşılmaktadır. Kullanılan İskit/ Saka terimi hem bir tarihsel dönemi (M.Ö. IV-III. yy) hem de kazılarda ele geçen maddi kültür unsurlarıyla tanımlanabilen belirli bir arkeolojik kültürü ifade etmektedir.

\section{Kaynakça}

Çernikov, S. (1975). K voprosu o hronologiçeskih periodah v epohu rannih koçevnikov (po arheologiçeskim materialam Vostoçnogo Kazahstana). Pervobıtnaya arheologiya Sibiri (A. Mendelştam, Ed.) 132-137.

Dzhumabekova, G., Bazarbayeva G., Glushkova. T. (2010). Kostyum drevnih bereltsev: Popitka rekonstruktsii. Integratsiya arheologiçeskih i etnografiçeskih issledovaniy: sbornik nauçnı trudov, Cilt 1, 307-309.

Gorbunov, A., Samashev, Z., Severski, E. (2005). Sokrovisha merzlih kurganov Kazahskogo Altaya (po materialam mogilnika Berel). Almatı, TOO İl-Teh Kitap.

Gryaznov, M. (1930). Drevnie kulturı Altaya. Materialı po izuçeniyu Sibiri, Novosibirsk: Obşestvo izuçeniya Sibiri, 2, 18-26.

Gryaznov, M. (1939). Rannie koçevniki zapadnoi Sibiri i Kazahstana. İstoriya SSSR $s$ drevneişıh vremen do obrazovaniya drevnerusskogo gosudarstva, C I-II (na pravah rukopisi), Moskva. Leningrad, 399-413.

Gryaznov, M. (1950). Pervii Pazırıkskiy kurgan. İzdatelstvo Gosudarstvennogo Ermitaja.

Gryaznov, M. (1992). Altay i prialtayskaya step. Arheologiya SSSR: Stepnaya polosa Azyatskoi çasti SSSR v skifo-sarmatskoe vremyai Moskva, 161-178.

Hudyakov Yu. (1986) Voorujeniye srednevekovıh koçevnikov Yujnoy Sibiri i Centralnoy Azii. Nauka, Novosibirsk.

Kadırbayev, M. (1977). Vostoçnıy Kazahstan. Ístoriya Kazahskoi SSR, C.1, Alma-Ata.

Kashkinbayev, K. (2013). Berel jllkıları, paloepatalogiyallk zertteuler. Astana: A. H. Margulan atındagı Arheologiya İnstitutı Astana kalasının filiyalı.

Kashkinbayev, K., Samashev Z. (2005). Loşadi Drevnih Koçevnikov Kazahskogo Altaya. Almat1.

Kisilev, S. (1935). İz rabot Altayskoi ekspeditsii Gosudarstvennogo İstoriçeskogo muzeyia 1934 goda. Sovetskaya etnografiya, 1, 97-106 
Kisilev, S. (1951). Drevnaya İstoriiya Yujnoi Sibiri. Moskva.

Kosintsev, S., Samashev Z., (2014). Berel jllkılarl, morfologiyalık zertteu. Astana: A. H. Margulan atındagı Arheologiya İnstitutı Astana kalasının filiyalı.

Kubarev, V.,Shulga, P. (2007). Pazırıkskaya kultura (kurganı Çuya i Ursula): monografiya. Barnaul, Altay Üniversitesi.

Kubarev, G.V. (2005). Kultura drevnih tyurok Altaya (po materialam pogrebalnıh pamyatnikov). Novosibirsk.

Kutlu, M. (2020a). Orta Asya'da tütekli (kırlangıç) örtünün kökeni ve tarihî gelişi̇m aşamaları üzerine bir değerlendirme. History Studies, 12/5, 2455-2486.

Kutlu, M. (2020b). Eleke Sazı'nda geç tunç çağı̀na ait bir İskit kurganı. Kültür Araştırmaları Dergisi, 4/11, 144-156.

Kutlu, M. (2020c). Doğu Kazakistan'da Eleke Sazı Göktürk mezar külliyesi. Yekta Demiralp Anısına Sanat Tarihi Yazıları (Ş. Çakmak, E. Daş, B. Ersoy, S. Gök İpekçioğlu, İ. Kuyulu Ersoy ve H. Uçar, Ed.) İstanbul: Ege, 263-270.

Kutlu, M. (2020d). Keşfinin 50. yılında Esik kurganı ve altın elbiseli adam. Ege, İstanbul.

Kutlu, M. (2020e). Berel'deki 4. Kurgan. Asya Studies, 4(11), 58-70.

Kutlu, M., Kutlu, L. (2020). Berel'deki 11. Kurgan ve Pazırık kültürü. Sanat Tarihi Dergisi, 29/1, 173-207.

Kutlu, M. (2021) Eleke Sazı'ndaki 4. Kurgan ve “Altın Adam” buluntuları üzerine bir değerlendirme. Geçmişten Geleceğe Avrasya, (M. Aça ve M.A. Yolcu, ed.) Çanakkale: Paradigma Akademi, 57-75.

Kuzuoğlu, R., Gökçek L. (2005). 2003 yılı Bilge Kağan anıt mezar kazısı. Manas Üniversitesi Sosyal Bilimler Dergisi, 7 (13), 5-34.

Marsadolov, L. (1988). O date Bolşogo Berelskogo kurgana. Soobşeniya Gosudarstvennogo Ermitaja, 53, 24-26.

Mert, O. (2015). Köli Çor yazıtı ve anıt mezar kompleksi. Erzurum: Atatürk Üniversitesi.

Miller, G. (1937). İstoriya Sibiri. Moskva- Leningrad. Cilt 1.

Nikonorov V, Hudyakov Yu. (2004) Svistyaşiye strelı Maodunya i Marsov meç Atillı: Voennoe delo aziatskih Hunnu i evropeyskih Gunov, Filometis, Sankt-Peterburg.

Ongarulı, A. (2008). Kazak dalasındagı erte köşpelilerdin elitalık obaların toptau men jikteu maselelerine. Kazakstan Respublikası Ulttık gılımi akademiyasının habarları, 1, 110- 117.

Pritsak, O. (1954). Orientierung und Farbsymbolik Saeculum, V, 376- 383.

Radlov, V. (1989). Iz Sibiri: Stranitsı dnevnika (Aus Sibirien. Lose Blätter aus dem Tagebuch von Dr. Wilhelm Radloff. Leipzig, 1893). Almanca'dan aktaran Tsevina K. ve Çistova M. Moskva.

Roux, J.P. (2015). Eski Türk mitolojisi. Ankara: BilgeSu. 
Rudenko, S. (1953). Kultura naseleniya Gornogo Altaya v skifskoe vremya. Moskva, Leningrad. AN SSSR.

Rudenko, S. (1962). Kultura Hunnov i Noinulinskiye kurganı. Moskva, Leningrad.

Samashev, Z. (2011). Berel. Almat1: Taimas.

Samashev, Z. (2011b). Nekotorıe Rezultatı İssledovaniy Berelskih Kurganov. Materialı mejdunarodnogo simpoziuma "Terra Scythica". Novosibirsk, İnstitut arheologii i etnografii SO RAN, 218-238

Samashev, Z. (2012). Veshevoi kompleks Berelya: Sostav i Soderjanie. Arheologiya $i$ Ístoriya Sarıarki. SBNS. Karaganda, İzdatelstvo KarGU, 195-222.

Samashev, Z. (2012). Nomads and networks, the ancient art and culture of Kazakhstan. Institute for the Study of Ancient World at NYU and Princeton University Press

Samashev, Z. (2013a). Kon v ritualno-obryadovoi praktike drevnego naseleniya Kazahskogo Altaya. Türik Düniyesi. Almanah. Almatı, 616-625

Samashev, Z. (2013b). Kazak öneri: 5 tomdık. T.1.: Ejelgi öner, Almatı, Elnur

Samashev, Z. (2017). Kompleksnıe metodı issledovaniya Berelskih Kurganov. Multidisciplinarniye metod $v$ arheologii, Novosibirsk, 284-296

Samashev, Z. (2018). Otız altınşı korgan. Kazak gılımi-zertteu madeniyet institutının baspa tob1, Astana.

Samashev, Z.\& Mylnikov, V. (2004). Derovoobrabotka u drevnih skotovodov Kazahskogo Altaya. Almati: OF Berel.

Samashev, Z., Bazarbaeva G., Jumabekova G., Sungatai S. (2000) Almatı: Berel Albom.

Samashev Z., Bokovenko N., Ahmadiyev Zh., Chotbayev A., Kariyev E., Tolegenov E., Samashev S., Kiyasbek G., Zhalmaganbetov Zh., Yerbolatov S. (2016) Nekotorıe itogi issledovaniy na nekropole Berel v 2016.g. Altay Türki Aleminin Altın Besigi, D. Akhmetov editörlüğünde, Öskemen, 234-252

Samashev, Z., Chotbayev, A., Kariyev E., Kiyasbek, G., Samashev, S., Ahmadiyev, Z. (2018). Kazak Altayı Madeni Tarihındagı Berel. Öskemen, Berel Memlekettik tarihi- madeni muzei-korik.

Samashev, Z., Kariyev, E., Aleksandrov, S., Ahmadiyev, J., Kiyasbek, G., Tolegenov, E., Samashev, S., Erbolatov, S. (2018). V1kladki-Ogradki Perioda Syanbi na Berele-Novii Etalonnıi Pamyatnik Epohi Velikigo Pereseleniya Narodov. Altay Türki Aleminin Altın Besigi, Daniyal Ahmetov editörlüğünde,Öskemen, 15-20

Samashev, Z., Kariyev, E., Erbolatov, S. (2019). Hunnu- Syanbeyskiy Kulturno- Hronologiçeskiy Gorizont Berelya. Margulan okuları 2019: Körnekti kazakstandık arheolog K.A. Akişevtın 95 jıldıgına arnalgan Halıkaralık arheologiyalık gilımi-tajribelik konferenciya materiyaldarl, Nur-Sultan, 385-393.

Shulga, D.P., Shulga P.İ. (2016). Arhitektura pogrebalno-pominalnıh kompleksov pazırıkskoy kulturı i osobennosti ih arheologizatsii. Balandinskiye Çteniya, Novosibirsk, 11, 72-76 
Shulga, P.İ., Myglan, V.S., Slusarenko, Y.İ. (2016). Hronologiya mogilnikov pozdnego etapa pazırıkskoy kulturı: dendrohronologiçeskaya şkala i arheologiçeski aspekt. Altay among the Eurasian antiquities (ed. A.P. Derevyanko ve V.İ. Molodin), IAET SB RAS Publishing, 272-285

Sorokin, S. (1969). Bolshoi Berelski Kurgan: Polnoye izdaniye materialov raskopok (1865 i 1959 gg.).Trudy Gosudarstvennogo Ermitaja, Leningrad, 7, 208-236

Surazakov, A.S. (1989). Gorniy Altay i ego severnye predgorya v epohu rannego jeleza. Problemı hronologii i kulturnogo razgraniçeniya. Gorno-Altaysk.

Taşağıl, A. (2017). Eski Türk boyları. Çin kaynaklarına göre. (M.Ö. III.-M.S.10.asır) İstanbul: Bilge Kültür Sanat.

Üren, U. (2015) Türklerde at kurbanı ve Dede Korkut’taki izleri. Türk Dünyası Incelemeleri Dergisi, 15/2, 65-74.

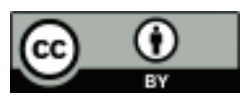

Bu eser Creative Commons Atıf 4.0 Uluslararası Lisansı ile lisanslanmıştır. (This work is licensed under a Creative Commons Attribution 4.0 International License). 